\title{
Ablative therapies for hepatic and biliary tumors: endohepatology coming of age
}

\author{
Jinendra Satiya $^{1 \#}$, Ingrid Schwartz ${ }^{2 \#}$, James H. Tabibian ${ }^{3,4}$, Vivek Kumar ${ }^{5}$, Mohit Girotra ${ }^{6}$ \\ ${ }^{1}$ Internal Medicine, University of Miami/JFK Medical Center Palm Beach Regional GME Consortium, West Palm Beach, FL, USA; ${ }^{2}$ Internal \\ Medicine, University of Miami Miller School of Medicine/Jackson Memorial Hospital, Miami, FL, USA; ${ }^{3}$ Geffen School of Medicine, University of \\ California, Los Angeles, CA, USA; ${ }^{4}$ Division of Gastroenterology, Department of Medicine, Olive View-UCLA Medical Center, Sylmar, CA, USA; \\ ${ }^{5}$ Gastroenterology and Hepatology, UPMC Susquehanna, Williamsport, PA, USA; ${ }^{6}$ Division of Gastroenterology and Hepatology, University of \\ Miami Miller School of Medicine, Miami, FL, USA \\ Contributions: (I) Conception and design: M Girotra; (II) Administrative support: M Girotra; (III) Provision of study materials or patients: J Satiya, \\ I Schwartz; (IV) Collection and assembly of data: J Satiya, I Schwartz; (V) Data analysis and interpretation: J Satiya, I Schwartz, JH Tabibian; (VI) \\ Manuscript writing: All authors; (VII) Final approval of manuscript: All authors. \\ \#These authors contributed equally to this work. \\ Correspondence to: Mohit Girotra, MD, FACP. Assistant Professor of Clinical Medicine, University of Miami Miller School of Medicine, Director of \\ Endoscopy, Division of Gastroenterology and Hepatology, University of Miami Hospitals and Clinics (UMHC), 1120 NW 14th Street (D-49), 1111 \\ CRB, Miami, FL 33136, USA. Email: mgirotra@med.miami.edu.
}

\begin{abstract}
Ablative therapies refer to minimally invasive procedures performed to destroy abnormal tissue that may arise with many conditions, and can be achieved clinically using chemical, thermal, and other techniques. In this review article, we explore the different ablative therapies used in the management of hepatic and biliary malignancies, namely hepatocellular carcinoma (HCC) and cholangiocarcinoma (CCA), with a particular focus on radiofrequency ablation (RFA) and photodynamic therapy (PDT) techniques.
\end{abstract}

Keywords: Ablative therapies; radiofrequency ablation (RFA); photodynamic therapy (PDT); cholangiocarcinoma (CCA); hepatocellular carcinoma (HCC)

Received: 03 April 2019; Accepted: 23 October 2019; Published: 05 April 2020.

doi: $10.21037 / \operatorname{tgh} .2019 .10 .17$

View this article at: http://dx.doi.org/10.21037/tgh.2019.10.17

\section{Introduction}

Ablative therapies refer to minimally invasive procedures performed to destroy abnormal tissue that may arise with many conditions. Ablation can be achieved clinically using chemical, thermal, and other techniques. Chemical ablation is usually performed using ethanol or $5 \%$ acetic acid. It causes tissue ischemia by inducing coagulation necrosis, and is usually a simple and low-cost procedure; however, has relatively high recurrence rates, which limits its use to smaller lesions. Chemical ablation has been described mainly for hepatocellular carcinoma (HCC) and neuroendocrine tumors. Thermal ablation can be achieved using cryotherapy or heat in the forms of radiofrequency [radiofrequency ablation (RFA)], photodynamic therapy
(PDT), microwave [microwave ablation (MWA)] or laser. Thermal ablation has been used for numerous lesions, including benign hepatic masses, Barrett's esophagus, cardiac arrhythmogenic foci, uterine fibroids, breast, kidney, pancreas, biliary, liver, and bone malignancies, and sarcomas, among other abnormal tissues (1-3). These respective thermal therapy techniques utilize various forms of thermal for curative and/or palliative treatment of primary and secondary hepatobiliary malignancies and nonmalignant lesions. Irreversible electroporation (IRE) is a nonthermal ablative technology that applies a high voltage electrical current across the tumor inducing cellular death. IRE is used mainly for hepatic metastasis and HCC, though it can also be used for pancreatic and other tumors $(1,4)$.

In this review article, we explore the different ablative 


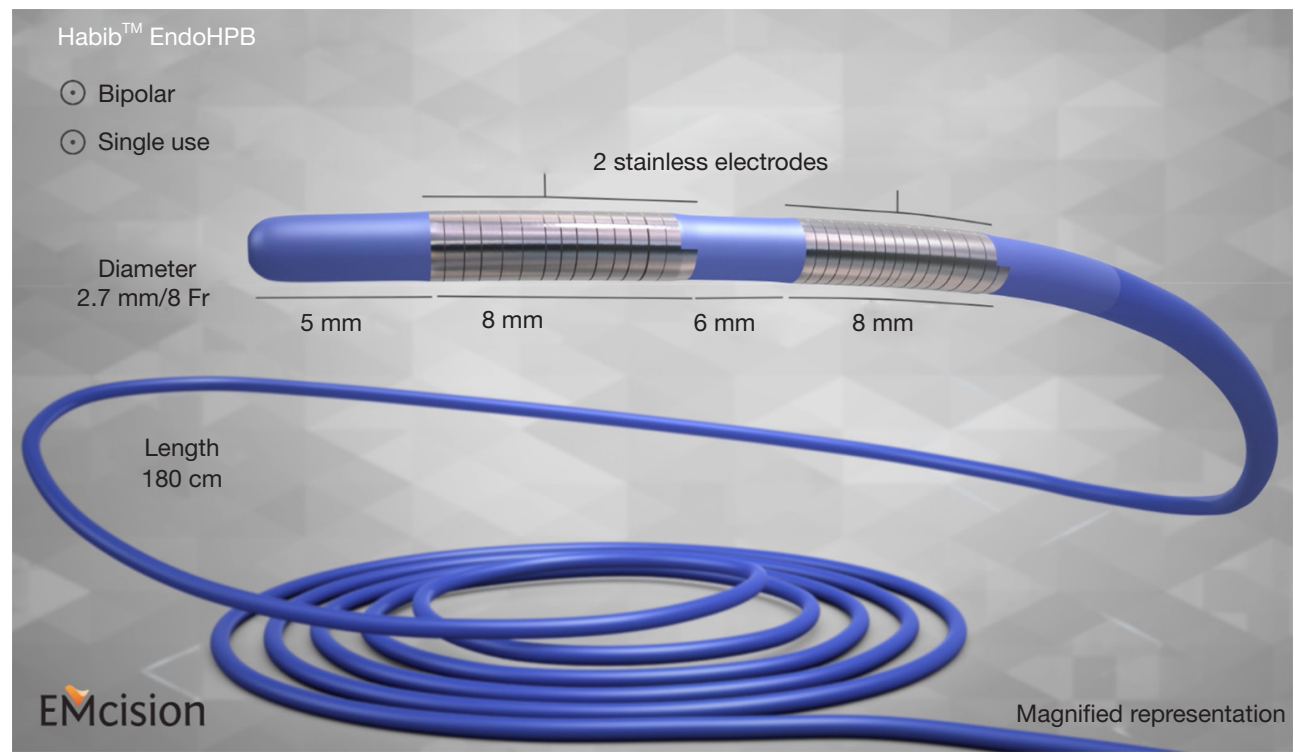

Figure 1 Habib ERCP probe: single use $180 \mathrm{~cm}$ length, $8 \mathrm{Fr}(2.6 \mathrm{~mm})$ diameter, fits over 0.035 " guidewire (picture used with permission from Boston Scientific, MA, USA). ERCP, endoscopic retrograde cholangiography.

therapies used in the management of hepatic and biliary malignancies, namely HCC and cholangiocarcinoma (CCA), with a particular focus on RFA and PDT techniques.

\section{RFA procedure}

RFA employs high-frequency alternating current, which initiates temperatures ranging from $60-100^{\circ} \mathrm{C}$, triggering frictional heating, resulting in a change in direction of ionic flow within the tissue, with heat conduction homogenously in all directions, to destroy solid tumor tissue. Three types of electrodes can be used: multitined expandable, internally cooled, and perfusion electrodes. RFA is a feasible and overall safe procedure that can provide local tumor control in patients with unresectable hepatobiliary tumors and/ or can be performed intra-operatively as an adjuvant to surgery. RFA is also used to treat tumor ingrowth in patients with uncovered self-expanding metallic stents (SEMSs), thus improving biliary stent patency. The 5 -year survival rates in HCC are estimated at 39.9-68.5\% (5-10). In a 10 -year study of 1,170 primary HCC patients in whom 2,982 RFA treatments were performed, survival rates were $60.2 \%$ and $27.3 \%$ at 5 and 10 years, respectively (5). Local tumor progression (LTP) rates after RFA range from $2.4 \%$ to $27.0 \%$ (5-10). Various studies have reported mortality from RFA to be between $0.9 \%$ and 7.9\% (5-10). The Habib ${ }^{\mathrm{TM}}$ EUS-RFA probe (1 Fr diameter, 190-cm long) is a novel device that can be used for RFA, passed through instrument channel of echoendoscope, to achieve coagulation of target tissue (HCC or intrahepatic CCA). A similar device is available now for use with endoscopic retrograde cholangiography (ERCP), as depicted in Figure 1.

\section{PDT procedure}

During PDT, a laser is used to activate a chemical photosensitizer that accumulates in malignant cells, thereby ablating the malignant tissue (3). PDT is well described in the treatment of various neoplastic lesions. Preparation for PDT involves intravenous administration of the photosensitizing agent, $2 \mathrm{mg} / \mathrm{kg}$ of porfirmer sodium (Photofrin; Axcan Pharma Inc., Birmingham, AL, USA), administered 48 hours before laser activation, that preferentially accumulates in malignant cells. Activation can be delivered percutaneously or endoscopically via ERCP. Antibiotic prophylaxis is usually given for those with expected incomplete biliary drainage (11). With the endoscopic approach, after a cholangiogram is performed to better delineate the location of the malignant stricture, balloon or bougie dilation of the stricture(s) is performed. Then, a 3.0-m-length PDT optical fiber is inserted using radiographic visualization or direct visualization using cholangioscopy (12-14). With the catheter in place, 
photoactivation is delivered and plastic stent is placed afterwards. If performed using percutaneous approach, a guidewire followed by a guiding catheter can be used to traverse the stricture, followed by insertion of optical fiber under fluoroscopic guidance. After light activation, a percutaneous biliary tube is inserted to ensure biliary drainage $(11,15,16)$.

\section{CCA}

CCAs are tumors that arise from the cells that line the biliary tree, account for about $3 \%$ of gastrointestinal (GI) neoplasms, and its overall incidence has been increasing across the world $(17,18)$. CCAs can be classified according to its anatomical location as intrahepatic (iCCA), perihilar (pCCA), and distal (dCCA). Further classification of pCCA was described by Bismuth and Corllete as follows: type I (tumor involving common hepatic duct below the biliary confluence), type II (tumor affecting hepatic bile duct confluence, no invasion above the confluence), type III (tumor involving right or left hepatic duct in addition to the confluence), type IIIa (tumor involving right hepatic duct and biliary confluence), type IIIb (tumor involving left hepatic duct and biliary confluence), and type IV (tumor involving the confluence, both right and left hepatic ducts, and in addition secondary intra-hepatic system or involving multiple discontinuous sites in the right and left ducts). This system was first described in 1975 (19) and has been since then the most commonly used tool to classify pCCA. DeOliveira and colleagues recently published a new system for CCA classification taking into account tumor size and extent within biliary system, vascular (hepatic artery/portal vein) and lymph node involvement, distant metastases, and estimated post-resection hepatic volume (20).

Therapy for CCA is guided by the anatomical location of the tumor. Overall, curative surgical resection is the goal for resectable lesions. Chemotherapy and/or radiation therapy are used for non-curative/unresectable resections or as (neo)adjuvant modality for resectable lesions. The use of loco-regional therapies such as RFA, transarterial chemoembolization (TACE) and transarterial radioembolization (TARE) have been described for unresectable iCCA, which have a particularly poor prognosis and limited therapeutic options. Select patients with pCCA can be offered liver transplantation (LT), especially if associated with primary sclerosing cholangitis (PSC). Systemic or local chemoradiation have been described for unresectable pCCA, as well as local ablation therapies, as described further in this article. Systemic chemotherapy and palliative biliary drainage are the main stay of therapy for unresectable dCCA $(17,18)$, which can be achieved with plastic stents or SEMS. A large number of patients present with jaundice, and biliary drainage is often needed even in resectable tumors, while awaiting surgical intervention. Plastic stents are known to obstruct earlier than SEMS due to biofilm formation and smaller caliber; SEMS usually remain patent for 6-12 months and are generally preferred in patients pursuing a palliative approach (21).

\section{Role of RFA in CCA}

RFA has been used as neoadjuvant therapy for malignant biliary strictures to prolong stent patency. Its use is described in intrahepatic and extrahepatic CCA, pancreatic cancer, HCC, gallbladder cancer and ampullary neoplasms (22). The majority of reports describe biliary RFA to manage strictures before placing a stent, while a few propose RFA for the management of obstructed SEMS.

Both endoscopic-guided and percutaneous RFA are shown to be feasible and safe procedures, with high technical success and few procedure-related complications. Post-procedure abdominal pain, which is usually mild and subsides with analgesics, is one of the main complications described in both techniques, more prominent with the percutaneous than endoscopic approach. Percutaneous RFA is shown to have higher association with bleeding, whereas endoscopic RFA is associated with higher post-procedure pancreatitis. Table 1 lists the various studies utilizing RFA, and various reported adverse events, including cholangitis, sepsis, hemobilia, hepatic abscess, and stent migration. One study reported partial liver infarction as a result of thermal injury induced by RFA (23). There were 2 deaths related to hemobilia (occurred 4-6 weeks after RFA) (24) and 2 deaths associated with biliary sepsis (23).

A biliary stent is placed after ablation in the majority of cases (in all studies reviewed, except for one), with a SEMS comprising the majority. Sharaiha et al. noted no statistically significant association between stent type and stricture improvement $(\mathrm{P}=0.35)$, albeit a higher complication rate in those with plastic stents $(\mathrm{P}=0.007)$ (33). Stent patency at 30 days was $95-100 \%$ among various studies $(32,33,36,37)$, though long-term patency varied considerably, with a median of 84.5 to 270 days (average 160 days).

Three studies have compared RFA plus stenting versus stenting alone. A retrospective study of 26 patients by Li et al., where 12 underwent RFA and stenting and 14 


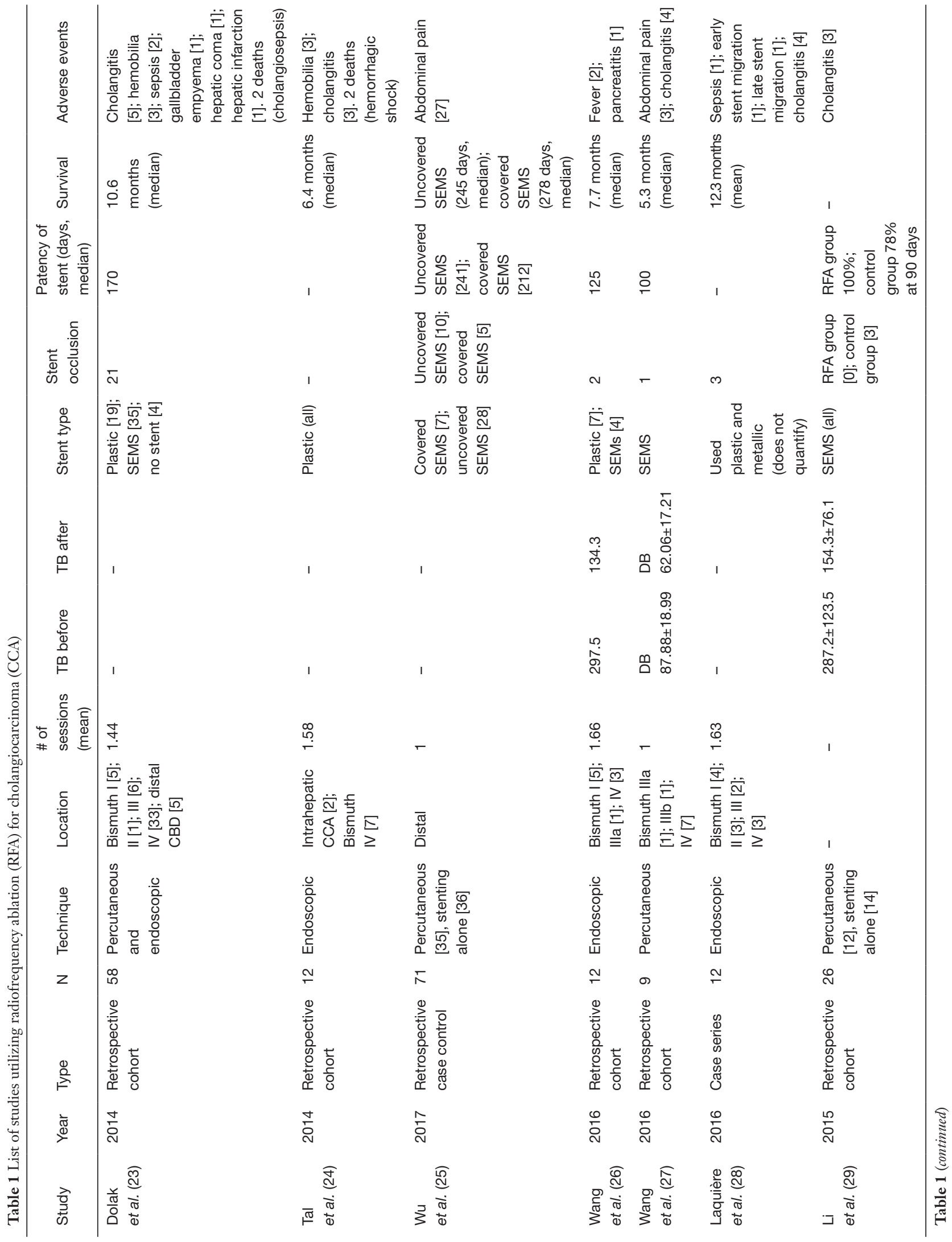




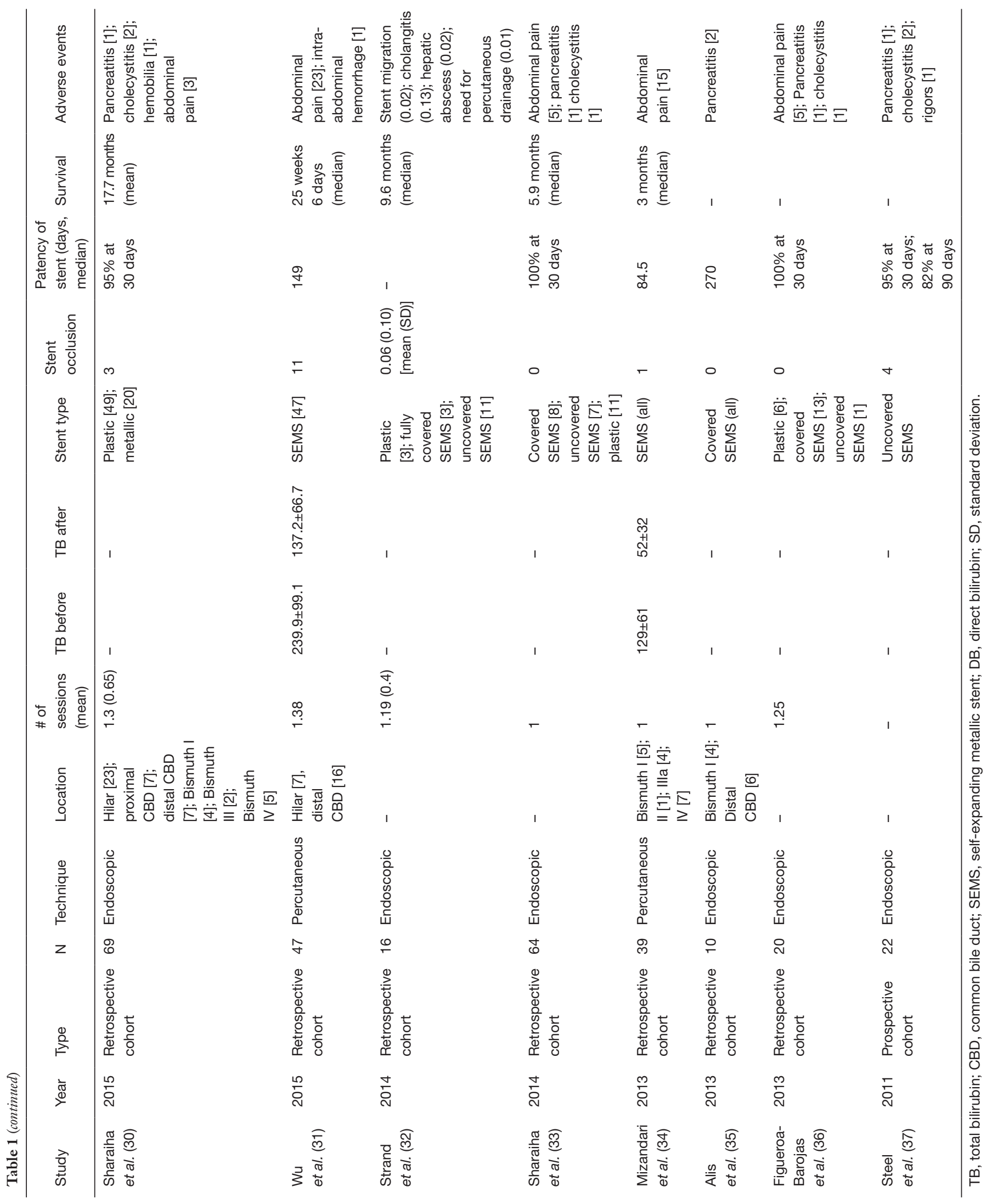


underwent stenting alone, stent patency at 6 months was noted to be significantly higher in the RFA plus stenting group than in stenting alone group ( $81 \%$ vs. $35 \%, \mathrm{P}<0.05)$ (29). Similarly, Wu et al. demonstrated that patients in RFA group had longer patency of uncovered SEMS $(\mathrm{P}=0.001)$; and in addition, a higher functional wellbeing assessed using the Functional Assessment of Cancer Therapy-Hepatobiliary (FACT-Hep) questionnaire (25). Sharaiha et al. reported similar stent patency in both the RFA and RFA plus stent (SEMS) group, and also noted a significant increase $(3.5 \mathrm{~mm})$ in bile duct diameter post-RFA $(\mathrm{P}<0.0001)(33)$.

As shown in Table 1, survival rates were variable among studies, ranging between 3 to 10.6 months. Median survival was not statistically significant in a study from $\mathrm{Wu}$ et al. comparing RFA and controls; in addition, they also reported similar survival rates between covered and uncovered SEMS (31). The Sharaiha group reported increased survival with RFA, in a study from 2015 (17.7 vs. 6.2 months, $\mathrm{P}=0.0001)$. They also reported $\mathrm{RFA}$ as a prognostic sign for survival [hazard ratio (HR) 0.29 (0.11-0.76), $\mathrm{P}=0.012$ ] $(30,33)$. Strand et al. compared RFA versus PDT in patients with unresectable CCA and found comparably improved overall survival in patients with unresectable CCA (32).

As a caveat, it should be noted that these studies are based on retrospective cohorts with a small number of patients. Additionally, limitations of RFA should be mentioned, including that it: (I) requires direct contact with the tissue, which prevents the treatment of inaccessible sites; (II) cannot target only malignant cells and thus damage of normal epithelium is a consequence; (III) cannot be used in pregnancy or patients with cardiac pacemaker or coagulopathy (38). Benefits of RFA, when compared with PDT, are notable and include: more cost-effective (cost of the RFA catheter is approximately USD \$1,295) (21), easier to perform (catheter can be inserted over a guidewire), and more practical for the patient (procedure done in one day and no need to avoid sunlight exposure).

\section{Role of PDT in CCA}

Similar to RFA, PDT has been used a palliative therapy for CCA in conjunction with biliary endoprostheses (22). Its use for biliary malignancies was first reported by McCaughan et al. in 1991, when the group used PDT for the treatment of a patient with common bile duct (CBD) adenocarcinoma over a course of 4 years (39). Procedure feasibility appears to approach $100 \%$, with biliary drainage improving following PDT; studies have found a decrease in post-procedure serum bilirubin levels when compared to pre-procedure, as illustrated in Table $2(12,16,40,46)$. A common procedure-related adverse effect of PDT is a photosensitivity reaction, though this is usually mild and self-limited. Other adverse effects (relevant to essentially all ablative procedures) include abdominal pain, cholangitis, sepsis, liver abscess and less likely hemobilia (12-16,40-47). There were 9 deaths related to biliary sepsis following PDT in the reviewed studies $(44,47)$.

Compared to biliary drainage procedures alone, survival appears to be longer in patients that receive PDT. Yang et al. performed a prospective evaluation where patients received $\mathrm{PDT}$ plus stenting versus stenting alone, and reported a statistically significant higher overall survival in the PDT plus stenting group $(14.9 \pm 5.8$ vs. $8.0 \pm 2.5$, $\mathrm{P}=0.002)$ (12). Three other trials were in accordance with these results: Kahaleh et al. (14) (better survival PDT vs. stent placement alone); Zoepf et al. (46) [significantly longer survival in the PDT group $v s$. biliary endoprosthesis group (21 vs. 7 months, $\mathrm{P}=0.01$ )]; Ortner et al. (47) [improved survival in PDT plus stenting vs. stenting alone (median 493 vs. 98 days, $\mathrm{P}=0.0001)]$. Two studies have compared PDT and surgical resection: Matull et al. reported that survival was similar in those undergoing palliative PDT compared to those undergoing curatively intended R1/R2-resections; surgery conferred survival benefit only when R0-resection margins were achieved (48); Cheon et al. reported that levels of CA19-9, bilirubin, and T-stage were statistically significant predictors of survival in a univariate analysis of patients treated with PDT plus stent vs. stent alone (16). They identified higher T-stage and no biliary drainage as independent predictors of poor survival in patients with advanced hilar CCA (16).

The data comparing RFA and PDT is limited. In a retrospective study on unresectable CCA patients by Schmidt et al., 14 patients underwent RFA and 20 patients underwent PDT, to evaluate short-term effects of biliary drainage and adverse events as primary end-points. The authors reported a significant decrease in bilirubin levels 14 days after the procedure in the RFA group $(\mathrm{P}=0.046)$ but no significant decrease in the PDT group $(\mathrm{P}=0.67)$. More premature ( $<3$ months) stent replacements were necessary in the PDT group when compared to the RFA group $(\mathrm{P}<0.01)$, although adverse events were comparable between groups (49).

Overall, PDT for CCA is well-tolerated and seems to provide survival benefit over biliary decompression through endobiliary stenting alone. The biggest advantage 


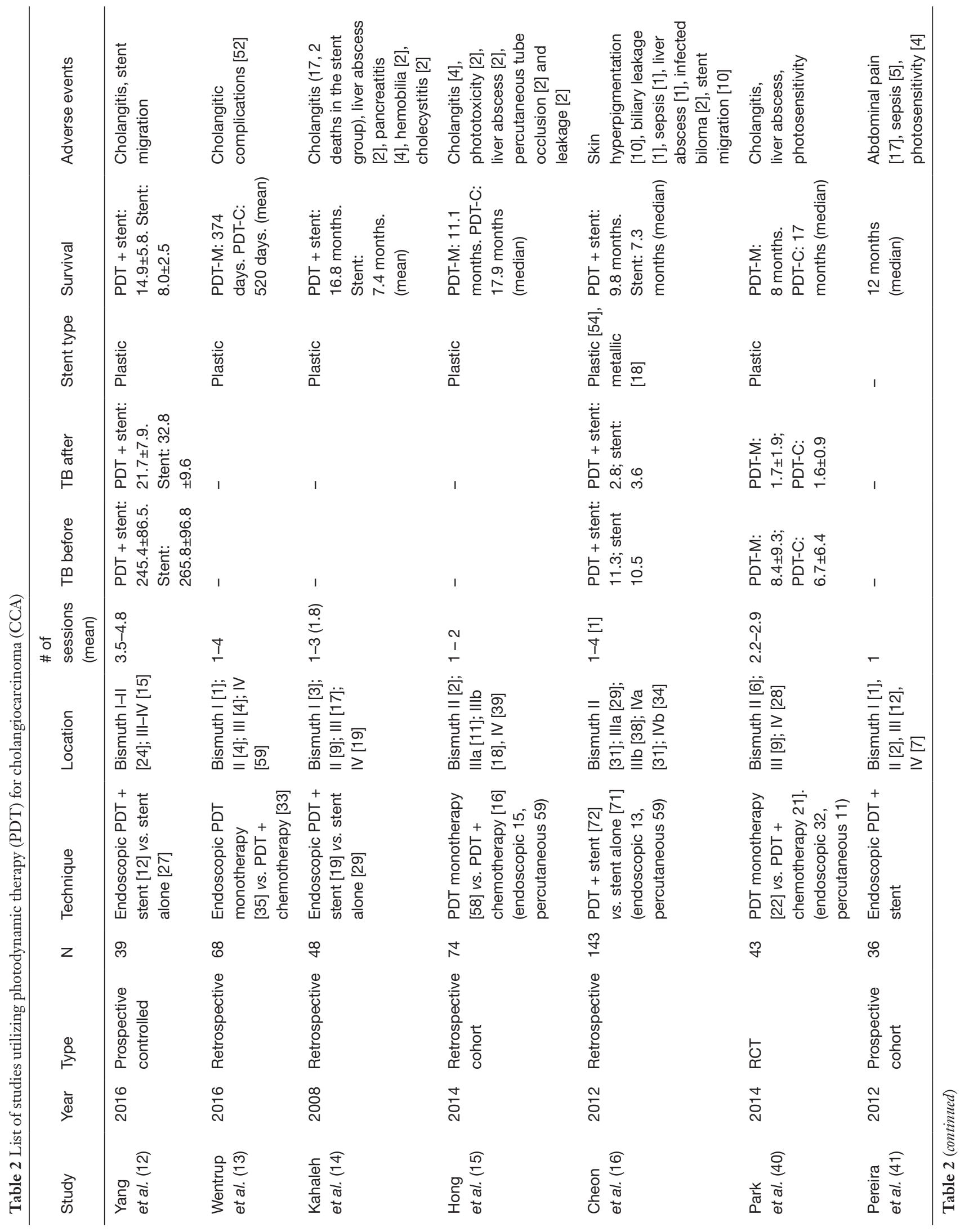




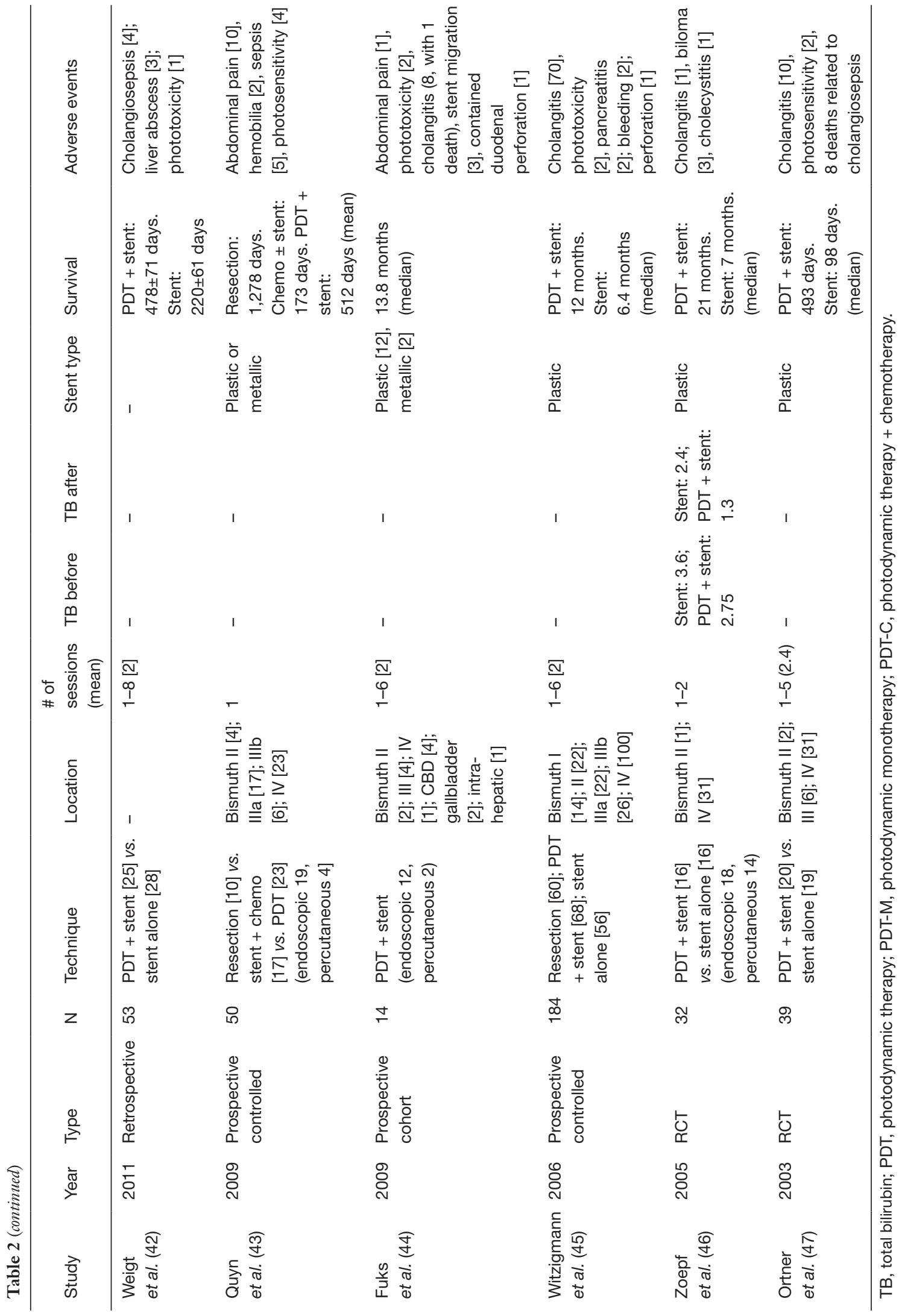


of PDT when compared to RFA is the ability to target the malignant cells, potentially sparing the healthy epithelium from damage, and the ability to refract through bile and treat obstructed biliary ducts that cannot be accessed. The disadvantages of PDT technique include: (I) the need to avoid direct and indirect light exposure for 4-6 weeks after the procedure in order to prevent photosensitivity; (II) the high-cost (single-dose of porfimer sodium for a $75-\mathrm{kg}$ patient may cost about USD \$37,208) (21).

\section{Other ablative techniques for CCA}

Intraluminal brachytherapy (ILBT), high-intensity intraductal ultrasound (IDUS), and MWA have also been described for palliation of CCA. ILBT involves seeding of the tumor with Iridium-192 and can be performed endoscopically and percutaneously. Studies reporting the use of ILBT for unresectable CCA have reached variable conclusions in terms of survival benefit (3). Another novel approach for unresectable hepatobiliary malignancies is the use of IDUS, performed by advancing a specialized ultrasound probe over a guidewire during ERCP, and applying several treatments throughout the lesion (38). Prat et al. reported their experience with using IDUS in 10 patients with biliary tumors, demonstrating tumor reduction in half of the patients $(n=3)$ that were treated for CCA $(n=6)(50)$. MWA is known to be efficient for HCC palliation and has now been described as an alternate approach for iCCA. Yu et al. suggested that MWA is a relatively safe and effective method to treat iCCA, with only minor periprocedural complications within 30 days (2).

\section{HCC}

HCC, the third highest cause of cancer-related mortality globally, continues to be the leading cause of death in patients with cirrhosis $(51,52)$. Common causes of HCC vary by geographical location: Infection with fungal aflatoxin B1 and chronic hepatitis B virus (HBV) account for most cases in the African sub-continent and East Asia, while most cases in North America, Japan and Europe can be attributed to alcoholism and hepatitis $\mathrm{C}(51,53)$. The diagnosis of HCC can be made using magnetic resonance imaging (MRI) and computerized tomography (CT), with classical features being evidence of arterial contrast uptake followed by washout in the delayed venous phase seen in the hepatic lesion in a patient with known cirrhosis. A number of factors, such as, residual liver function, tumor burden and scores such as the Karnofsky Index can help evaluate and approximate the odds of survival (54).

The Barcelona Clinic Liver Cancer (BCLC) scoring system has been widely accepted for staging and making management decisions. Candidates for resection, ablation or transplantation are stage BCLC-A patients (early-stage HCC with a solitary lesion without vascular invasion). The treatment of choice for patients with stage BCLC-B with preserved liver function (multifocal HCC with no evidence of vascular invasion or extrahepatic spread) is TACE. BCLC-C stage includes patients with extrahepatic spread and/or vascular invasion, and benefit from sorafenib therapy, while BCLC-D is at the end of the clinical spectrum with a poor prognosis. Spontaneous bacterial peritonitis (SBP), refractory ascites, hyponatremia, episodes of encephalopathy indicate end-stage cirrhosis classifying these patients as BCLC-D and precluding any anticancer therapy (55). The introduction of the Milan criteria brought about a global surge in the number of LTs for HCC, with a subsequent rise in the requirement of treatment options for patients on the waiting list (56-58). The Model for EndStage Liver Disease (MELD) score accurately predicts poor short-term outcome in cirrhosis and allows for the patients with the highest risk of imminent mortality to be moved up the transplant list.

Treatment options for HCC include LT, liver resection (LR), or local ablative therapies (59). A patient meeting the Milan criteria warrants a LT (60), which is dependent on donor availability, and may often have to endure long waiting periods on the transplant list with up to a year in the United States and Europe. During this time, tumors may progress and eventually prevent transplantation $(61,62)$. The importance of procedures such as TACE, RFA and percutaneous ethanol injection (PEI) lies in delaying the progression of tumors during this time interval (63).

\section{Ablative therapies for HCC}

Various local ablation techniques have been increasingly employed to overcome this clinical dilemma. Among these, image-guided percutaneous ablation is considered the best in the treatment of early-stage HCC, and may include ethanol injection (64,65), MWA (66), RFA (67-69), IRE, and cryoablation. Ablation can be curative, is minimally invasive, and can be repeated for recurrence. For patients with Child-Pugh A or B cirrhosis with not more than three tumors measuring 3 centimeter each, ablation is the treatment of choice. RFA provides a safe, minimally invasive 
and technically simple option for these patients.

Györi et al. compared single versus multimodality locoregional treatment (LRT) strategies on outcomes after LT in 150 patients (Table 3) (70). They demonstrated that patients who underwent multimodality LRT (mmLRT) did worse after LT, as compared to those exposed to one LRT. They concluded that a single LRT showed better survival outcomes up to 5 years after LT, and TACE and RFA showed comparable post-LT survival.

\section{Role of RFA in HCC}

RFA is widely accepted as the treatment of choice for HCC patients that are not candidates for resection, and additionally as bridge therapy, to delay the progression of tumor in patients on the transplant list (80-88). The success of RFA is inversely proportional to the tumor size. Complete remission (CR) after RFA for $\mathrm{HCC} \leq 2 \mathrm{~cm}$ is approximately $90 \%$ (89), while for HCC >2 cm, the LTP rate is substantial, varying from $20 \%$ to $40 \%(90,91)$. Prevention of LTP and distant HCC recurrence depends on the ability to obtain complete coagulation necrosis of the tumor and a sufficient safety margin. RFA is a relatively safe procedure with a procedure-related mortality rate of $0.2 \%$ and complication rate approximately $2.2 \%$ (92).

Hao et al. showed that RFA for typical HCC's resulted in a slowing of rate of tumor progression (71). Interestingly, while post RFA progression of early-HCC $(n=50)$, defined as those in early stages of carcinogenesis $(75,93-95)$, was minimal (2/50), about 24.6\% (46/187) typical HCCs exhibited local recurrence after RFA (71). Liao et al. described the benefit of RFA in reducing tumor incidence in patients with small HCC secondary to cirrhosis (72). In 96 patients randomized to undergo wide margin ablation (WM $=10 \mathrm{~mm}$ ablation margin, $\mathrm{n}=48$ ) or normal margin ablation ( $\mathrm{NM}>5 \mathrm{~mm}$ but $<10 \mathrm{~mm}$ ablation margin, $\mathrm{n}=48$ ), 3 -year incidences of LTP was $14.9 \%$ vs $30.2 \%$, intrahepatic recurrences (IHR) was $15.0 \%$ vs. $32.7 \%$, and recurrencefree survival (RFS) was $31.7 \pm 12.1$ vs. $24.0 \pm 11.7$ months respectively.

Rajyaguru et al. compared the effectiveness of RFA $(\mathrm{n}=3,684) v s$. stereotactic body radiotherapy (SBRT, $\mathrm{n}=296)$ in 2018 (73), and noted increased survival in RFA group for stage I and II HCC. Similarly, Parikh et al. compared RFA ( $\mathrm{n}=408)$ with SBRT $(\mathrm{n}=32)(74)$, and noted improved survival with RFA, and additionally identified increasing age, advanced disease and decompensated cirrhosis with poor survival. Praktiknjo et al. evaluated the response to local ablative therapy by measuring elastography using real-time 2D shear-wave elastography (RT 2D-SWE), and reported significant improvement in stiffness as early as three days after ablative therapy and proposed the use of RT 2D-SWE in helping identify HCC lesions amenable to ablative treatment (96).

Developments of new RFA techniques allow for a onesession complete ablation rate of $>90 \%$ for tumors $<5 \mathrm{~cm}$ in diameter. Laparoscopic RFA can be used for tumors in unusual locations and small lesions unidentifiable by preoperative imaging. Chen et al. (97), were the first to demonstrate comparable efficacy of RFA and surgical resection for single-nodule $\mathrm{HCC}<5 \mathrm{~cm}$ in diameter. Liu et al. reported an increased post-RFA recurrence rate at the previous site and a lower recurrence rate at new sites when compared to surgical resection (98).

Multicentric tumor lesions limit the efficacy of surgical treatment for HCC. While Elias et al. demonstrated good outcomes with the use of RFA for ablation of microscopic lesions in patients undergoing hepatectomy $(99,100)$, Choi et al. reported 1-, 3- and 5-year survival of laparoscopic resection (LR) + RFA comparable to surgical removal (101). Santambrogio et al. prospectively compared hepatic LR with laparoscopic ablative therapies (LAT) in 264 patients (76), and noted thermoablation to be an adequate alternative in patients with nodules that would require complex surgical resections, and in those with a poor prognosis. Recurrent HCC when treated with a repeat hepatectomy has shown poor outcomes and low 5-year survival rates (102-105). TACE and ethanol ablation was previously employed to treat recurrences in patients with low hepatic reserve, not amenable to surgery (106), RFA today is the treatment of choice for this patient population (107-115). The synergistic response of RFA with hepatectomy/LR has long been studied (116). Its use is limited by the high rate of intra and postoperative complications such as liver failure and death $(117,118)$, and additionally may leave behind treated tumor tissue in situ, and residual tumors or satellite nodules which can drastically reduce the success of this approach. When compared to LR, RFA offers the prospect of a minimally invasive approach with the added benefit of avoiding the development of postoperative intra-abdominal adhesion. Patients with recurrence on follow-up imaging studies (119) may still remain candidates for curative therapies and these above factors may be critical in patients who undergo subsequent LT.

RFA is limited by the heat-sink effect, defined as difficulties due to heating of charred tissue, often seen 


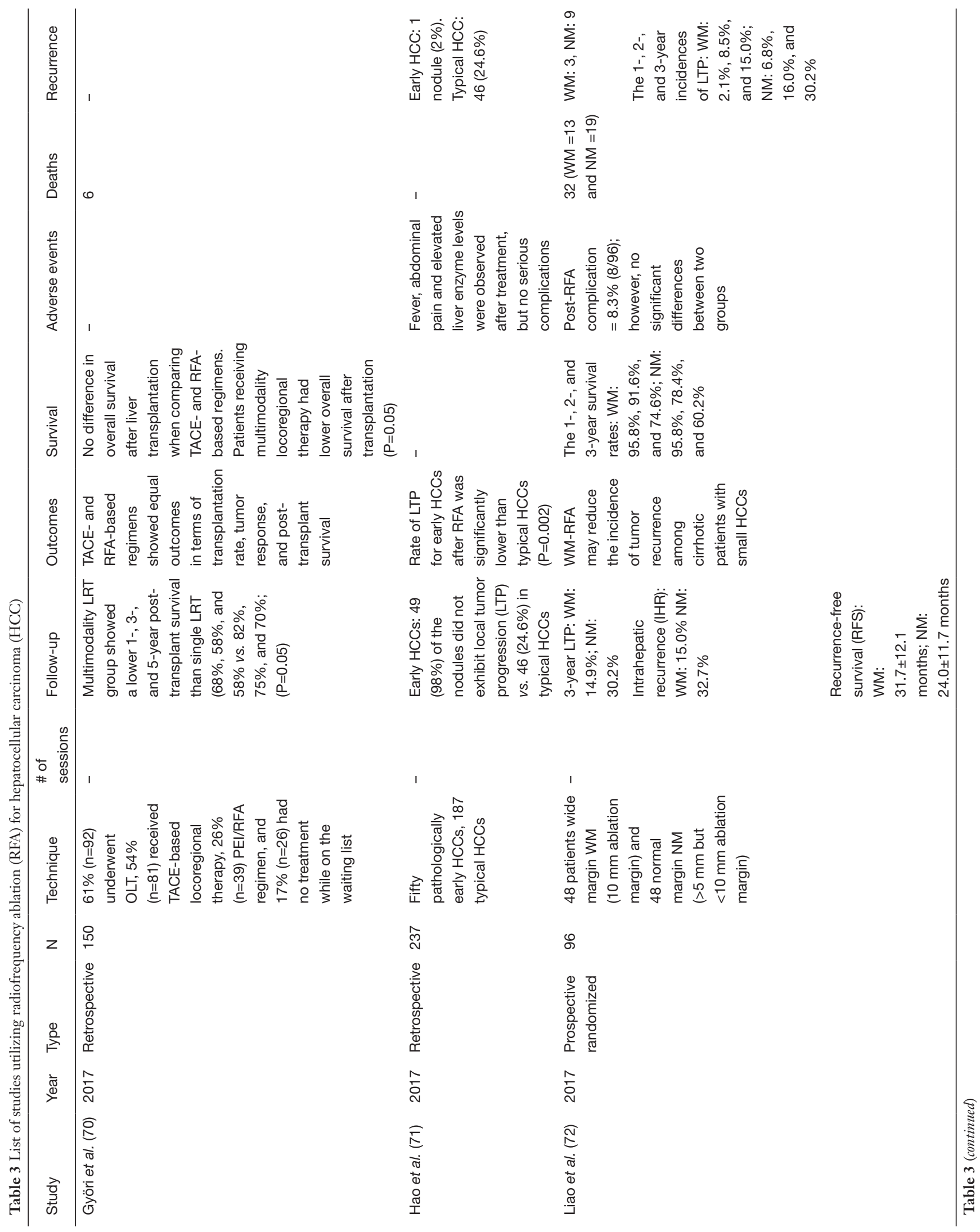




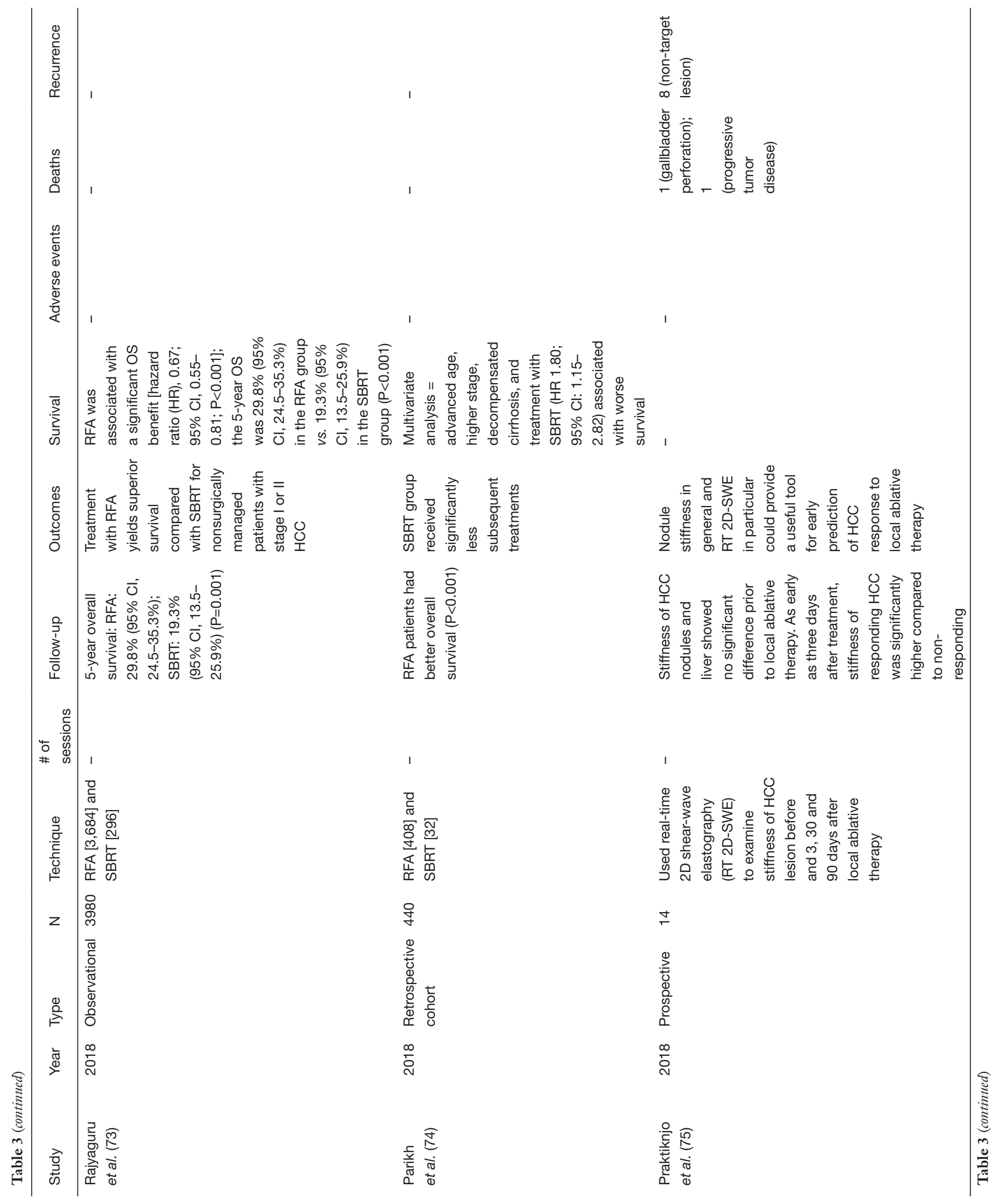




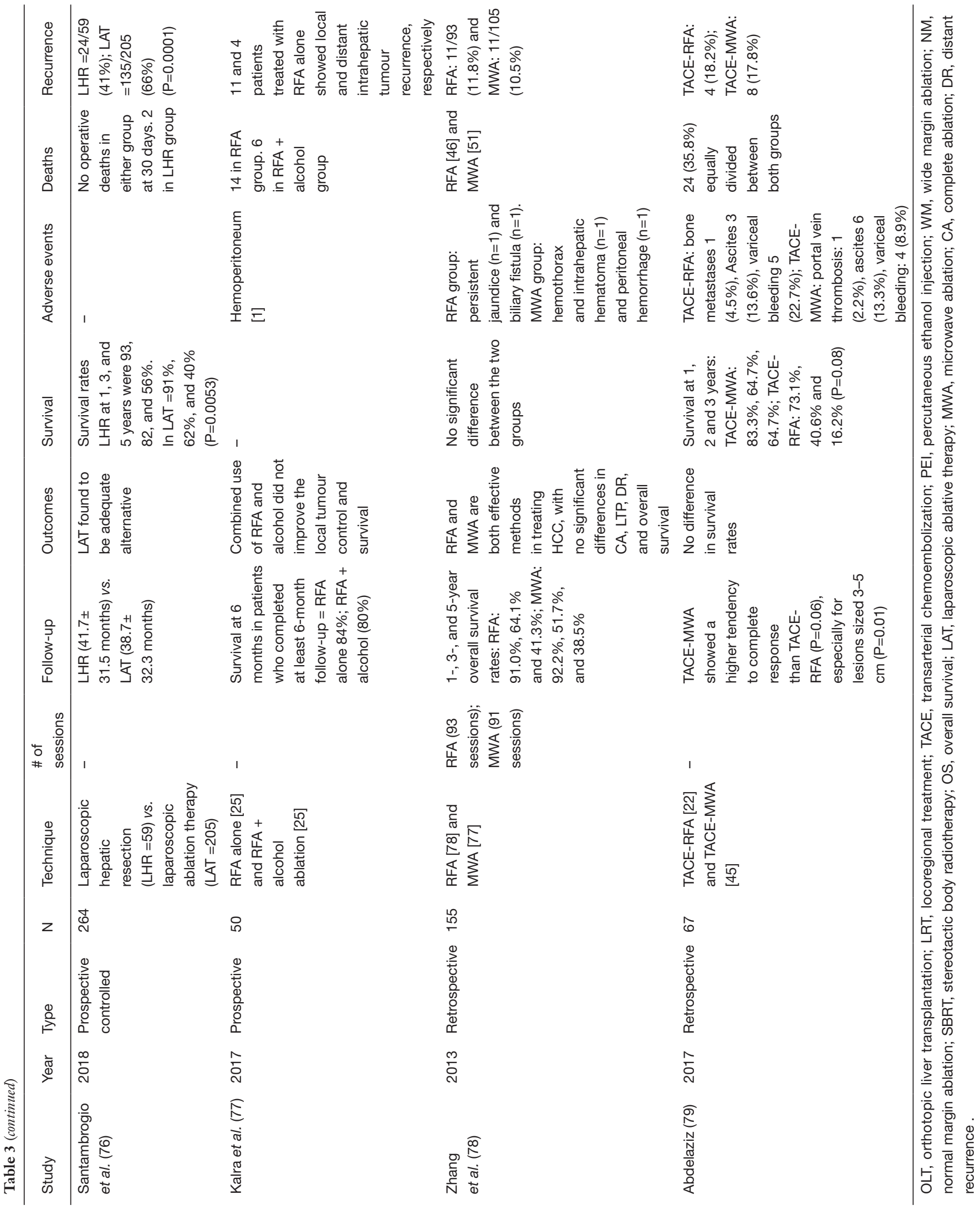


in tumors located near blood vessels. This can lead to inadequate ablation zones and a consequent higher rate of LTP (120). However, a combination of RFA with TACE may overcome this issue by their synergistic effect $(121,122)$. TACE decreases the heat sink effect by occluding hepatic arterial flow, thereby allowing for a larger RFA ablation zone. On the other hand, RFA induces hyperthermia, which can augment the anti-cancer effect of agents delivered by TACE. Outcomes can be improved with optimization of the duration between deliveries of these two treatments.

RFA is now being used increasingly in the treatment of HCC. Ten-year follow-up data supports it as a curative treatment and allows for long-term survival. Its minimally invasive nature makes it an attractive option, and it can be repeated easily for recurrence. Constant improvements in RFA devices and operation strategies have extended its application far beyond its initial use as a palliative measure (123).

\section{Role of PDT in HCC}

Patients with HCC with obstructive jaundice present a management dilemma. The presence of hemobilia, secondary to tumor, upon biliary intervention, often makes biliary drainage futile, thereby imparting a poor prognosis in these patients (124-130). Tang et al. first demonstrated the immunomodulatory effects of Pheophorbide-a PDT (PaPDT) on human cancer cells in vitro (131). Pheophorbide-a $(\mathrm{Pa})$ is a chlorophyll derivative, extracted from a Chinese herbal medicine Scutellaria Barbata with antitumor effects on a number of human cancers, and investigators found $\mathrm{Pa}-$ PDT to be a significant inhibitor of the growth of HepG2 cells (131). Since then, several studies have reported the immunomodulatory effects of PDT (132-138). Its principle is based on the use of a photosensitizer, activation of which results in interaction with molecular oxygen, producing reactive oxygen species (ROS) $(139,140)$. The ROS are directly cytotoxic to the tumor cells and trigger the immune reorganization of cancer cells, efficacy of which may depend on wavelength/dose of light and type/concentration of photosensitizer used, and also type of treated tissue (141).

Bahng et al. (Table 4) evaluated the safety and efficacy of PDT in 11 unresectable HCC patients with bile duct invasion in a prospective observational pilot study (142), and noted improvement in jaundice in $70 \%(7 / 10)$ of patients, and hemobilia was successfully controlled in $100 \%$ (6/6) of patients. Cholangitis was observed in 6 patients $(6 / 11)$ after PDT, which resolved with antibiotics. This study also showed that the typical photosensitizer dose is safe even in cases of advanced liver cirrhosis despite hepatic elimination of the photosensitizer. Mirzaei et al. evaluated the efficacy of Radachlorin-mediated PDT $\left(2^{\text {nd }}\right.$ generation photosensitizer) on human HCC $(143,146)$, and showed it can induce apoptosis in HepG2 cells with low phototoxic effects on normal liver cells (HFLF-PI4 cells).

Chang et al. utilized hematoporphyrin (HP)-modified doxorubicin (DOX)-loaded nanoparticles (HP-NPs) to enhance the PDT effect (144). HP is a ligand binding to low-density lipoprotein (LDL) receptors on tumor cell membrane $(147,148)$, but have poor aqueous solubility and tumor specificity (149), so drug delivery systems (lipid, polymer-based nanoparticles and polymer conjugates) have been developed to mitigate these drawbacks (150-152). Many studies have reported a synergistic antitumor efficacy of PDT and chemotherapy, in vivo and in vitro (153-156). Ismail et al. along with others have reported the enhanced efficacy of PDT with nano-sized formulations in treatment of HCC (157). Studies with other photosensitizers such as Photofrin are currently under way.

Shirata et al. developed a novel treatment modality with PDT, involving the use indocyanine green (ICG) and near-infrared (NIR) laser (145). ICG is a photothermal agent, photosensitizer, and fluorescence-imaging probe with a predilection for HCC cells, and has an excellent safety profile (158). ICG causes apoptosis of tumor cells in vitro and in vivo. ICG-NIR therapy can be employed for diagnosis and treatment of HCC. It can help surgeons identify residual tumors using the ICG fluorescence technique, and subsequent treatment of residual tumor tissue, as well as treatment of disseminated peritoneal lesions. Studies to confirm the survival benefits of PDT and a comparison with radiotherapy as a local treatment are required.

PDT is an attractive alternative treatment modality in patients with HCC with bile duct invasion, especially those complicated by hemobilia. It is a relatively well-tolerated procedure with cholangitis being the most common complication, which can be managed medically.

\section{Other ablative techniques for HCC}

\section{PEI}

First described in the early 1980s $(64,65,159)$, PEI is a welltolerated, cheap, and relatively safe procedure, with patient survival estimated at $38-60 \%$ at 5 years (160-163). Kalra et al. compared RFA alone versus RFA + PEI for small HCC 
Table 4 List of studies utilizing photodynamic therapy (PDT) for hepatocellular carcinoma (HCC)

\begin{tabular}{|c|c|c|c|c|c|c|c|c|}
\hline Study & Year & Type & $N$ & Technique & Aim & Outcomes & Survival & Adverse events \\
\hline $\begin{array}{l}\text { Tang } \\
\text { et al. (131) }\end{array}$ & 2010 & In vitro & NA & $\begin{array}{l}\text { The underlying } \\
\text { action mechanism } \\
\text { of Pa-PDT was } \\
\text { systemically } \\
\text { investigated with a } \\
\text { human hepatoma } \\
\text { cell line HepG2 }\end{array}$ & $\begin{array}{l}\text { To study and } \\
\text { evaluate the } \\
\text { immunomodulatory } \\
\text { effects of } \\
\text { pheophorbide a }\end{array}$ & $\begin{array}{l}\text { Pa-PDT significantly } \\
\text { inhibited the growth } \\
\text { of HepG2 cells. First } \\
\text { evidence that Pa- } \\
\text { PDT can trigger } \\
\text { both apoptosis and } \\
\text { cancer immunity in } \\
\text { the tumor host }\end{array}$ & NA & NA \\
\hline $\begin{array}{l}\text { Bahng } \\
\text { et al. (142) }\end{array}$ & 2013 & $\begin{array}{l}\text { Prospective } \\
\text { observational } \\
\text { pilot }\end{array}$ & 11 & $\begin{array}{l}\text { PDT with biliary } \\
\text { drainage with } \\
\text { plastic stent [5] and } \\
\text { uncovered metal } \\
\text { stent [6] }\end{array}$ & $\begin{array}{l}\text { To assess the safety } \\
\text { and efficacy of PDT } \\
\text { in unresectable } \\
\text { HCC with bile duct } \\
\text { invasion }\end{array}$ & $\begin{array}{l}\text { PDT is an effective } \\
\text { alternative treatment } \\
\text { option for HCC } \\
\text { with bile duct } \\
\text { invasion especially } \\
\text { complicated by } \\
\text { hemobilia }\end{array}$ & $\begin{array}{l}\text { Longer } \\
\text { and more } \\
\text { effective } \\
\text { relief of } \\
\text { the biliary } \\
\text { obstruction } \\
\text { can prolong } \\
\text { survival }\end{array}$ & $\begin{array}{l}\text { Cholangitis [6], } \\
\text { hemobilia [3] }\end{array}$ \\
\hline $\begin{array}{l}\text { Mirzaei } \\
\text { et al. (143) }\end{array}$ & 2015 & In vitro & NA & $\begin{array}{l}\text { Evaluated human } \\
\text { liver cancer cells } \\
\text { (HepG2) and normal } \\
\text { liver cells (HFLF- } \\
\text { PI4) for cell viability } \\
\text { using the standard } \\
\text { 2-(4, 5-dimethyl- } \\
\text { 2-thiazolyl)-3,5- } \\
\text { diphenyl-2H- } \\
\text { tetrazolium bromide } \\
\text { (MTT) assay }\end{array}$ & $\begin{array}{l}\text { To determine } \\
\text { in vitro efficacy of } \\
\text { Radachlorin-based } \\
\text { PDT (Radachlorin- } \\
\text { PDT) on human } \\
\text { hepatocellular } \\
\text { carcinoma (HCC) }\end{array}$ & $\begin{array}{l}\text { PDT with } \\
\text { Radachlorin can } \\
\text { be effective in the } \\
\text { treatment of HCC }\end{array}$ & NA & NA \\
\hline $\begin{array}{l}\text { Shirata } \\
\text { et al. (145) }\end{array}$ & 2017 & $\begin{array}{l}\text { In vitro and } \\
\text { In vivo }\end{array}$ & NA & $\begin{array}{l}\text { HuH-7 (a well- } \\
\text { differentiated } \\
\text { hepatocellular } \\
\text { carcinoma cell line) } \\
\text { cells and male mice }\end{array}$ & $\begin{array}{l}\text { To investigate } \\
\text { the mechanisms } \\
\text { underlying the anti- } \\
\text { tumor effect of ICG- } \\
\text { NIR therapy }\end{array}$ & $\begin{array}{l}\text { Apoptosis of HCC } \\
\text { cells after ICG-NIR } \\
\text { therapy is mediated } \\
\text { by photothermal } \\
\text { effect and oxidative } \\
\text { stress induced by } \\
\text { PDT, both in vitro } \\
\text { and in vivo. The } \\
\text { major advantage of } \\
\text { ICG-NIR therapy is } \\
\text { its high selectivity } \\
\text { for HCC tissues }\end{array}$ & NA & NA \\
\hline
\end{tabular}

NA, not available; Pa-PDT, Pheophorbide-a PDT; HP-NPs, hematoporphyrin-modified doxorubicin-loaded nanoparticles; ICG-NIR, indocyanine green near-infrared. 
prospectively in 50 patients (77), but found no difference in survival. In other studies, RFA and PEI are equally efficacious for solitary tumors less than 2 centimeters $(164,165)$.

\section{Cryoablation}

Cryoablation uses extremely low temperature, where both direct and indirect effects destroy tumor tissue (166). While direct toxicity is caused by ice-crystals, which cause cell dehydration and subsequent rupture, ischemic hypoxia as a result of vascular injury is responsible for the indirect toxicity (166). Cryoablation has an advantage given possibility of precise monitoring of ablated area during the procedure by various imaging modalities, such as CT, MRI, or ultrasound (167), therefore optimally controlling the treatment effects.

\section{MWA}

In MWA, tumor tissue is destroyed by direct hyperthermic injury produced by electromagnetic wave emitted from the non-insulated portions of the antenna. The first-generation MWA was used in clinical practice in the 1990s (66). MWA is considered to have physical advantages in comparison with RFA: a larger volume of active heating resulting in shorter procedure times, higher tissue temperatures beyond the threshold of water vaporization, and less susceptibility to the heat sink effect of blood flow (168-170). The new generation MWA systems incorporate water or gas antenna cooling and high-power generation (171). Zhang et al. in 2013 showed that RFA and MWA are both effective methods in treating HCC, with no significant differences in LTP, distal recurrence and overall survival (78). Further comparison studies between RFA and new-generation MWA are required.

\section{TACE and TARE}

The dominant arterial vascular supply of HCC provides the conduit for treatment with anticancer agents. TACE combines selective arterial obstruction with chemotherapy injection, and is currently the first-line treatment for BCLC-B patients, and decompensated cirrhosis being a contraindication to treatment. It is important to discontinue TACE at the onset of liver failure or no response. Appropriate patient selection can lead to median survival times of greater than four years. The use of drug-eluting beads that obstruct arterial vessels and slowly release chemotherapy have made the procedure well-tolerated (172). On the other hand, TARE is based on the action of beta-radiation delivered via yttriumloaded glass or resin spheres into blood vessels supplying tumor cells (173). It is a relatively well-tolerated procedure with reported survival rates comparable to TACE and sorafenib $(174,175)$. TARE is especially useful in patients with portal vein thrombosis. Koda et al. and Kuroda et al. compared RFA to RFA combined with TACE and reported no additional functional hepatic damage with combined therapy $(176,177)$. Abdelaziz et al. demonstrated higher response rates $(\mathrm{P}=0.06)$ in patients receiving treatment with TACE + MWA $(\mathrm{n}=45)$ as compared to those that received TACE + RFA $(n=22)$, the effect most pronounced in lesions measuring $3-5$ centimeters $(\mathrm{P}=0.01)(79)$.

\section{IRE}

IRE is a non-thermal ablation treatment that delivers short electric pulses to induce cell death due to apoptosis. The basic principle of IRE is to create irreversible pores in cellular bilipid membranes by subjecting them to a series of high voltage and high intensity electrical pulses for a short duration of time (178). IRE is a good alternative option for tumors located in close proximity to the porta hepatis $(179,180)$. IRE is invasive and requires general anesthesia. Further data on long-term outcomes are evolving.

\section{Conclusions}

The techniques of RFA and PDT are fairly established for patients with CCA and HCC and can be selected according to available expertise and various patient and tumor characteristics. Outcomes largely develop on these same variables but have been favorable overall. In addition, several other ablative strategies are starting to gain momentum, thus expanding the armamentarium of therapeutic options available to gastroenterologists, hepatologists, radiologists, oncologists, and surgical oncologists.

\section{Acknowledgments}

None.

\section{Footnote}

Conflicts of Interest: The authors have no conflicts of interest to declare.

Ethical Statement: The authors are accountable for all aspects of the work in ensuring that questions related to the accuracy or integrity of any part of the work are appropriately investigated and resolved. 


\section{References}

1. Hansen PD, Cassera MA, Wolf RF. Ablative technologies for hepatocellular, cholangiocarcinoma, and metastatic colorectal cancer of the liver. Surg Oncol Clin N Am 2015;24:97-119.

2. Yu MA, Liang P, Yu XL, et al. Sonography-guided percutaneous microwave ablation of intrahepatic primary cholangiocarcinoma. Eur J Radiol 2011;80:548-52.

3. Chahal P, Baron T. Endoscopic palliation of cholangiocarcinoma. Curr Opin Gastroenterol 2006;22:551-60

4. Lyu T, Wang X, Su Z, et al. Irreversible electroporation in primary and metastatic hepatic malignancies: A review. Medicine (Baltimore) 2017;96:e6386.

5. Shiina S, Tateishi R, Arano T, et al. Radiofrequency ablation for hepatocellular carcinoma: 10-Year outcome and prognostic factors. Am J Gastroenterol 2012;107:569-77.

6. Lencioni R, Cioni D, Crocetti L, et al. Early-stage hepatocellular carcinoma in patients with cirrhosis: longterm results of percutaneous image-guided radiofrequency ablation. Radiology 2005;234:961-7.

7. Tateishi R, Shiina S, Teratani T, et al. Percutaneous radiofrequency ablation for hepatocellular carcinoma. An analysis of 1000 cases. Cancer 2005;103:1201-9.

8. Livraghi T, Meloni F, Di Stasi M, et al. Sustained complete response and complications rates after radiofrequency ablation of very early hepatocellular carcinoma in cirrhosis: is resection still the treatment of choice? Hepatology 2008;47:82-9.

9. Yan K, Chen MH, Yang W, et al Radiofrequency ablation of hepatocellular carcinoma: long-term outcome and prognostic factors. Eur J Radiol 2008;67:336-47.

10. Kim YS, Lim HK, Rhim H, et al. Ten-year outcomes of percutaneous radiofrequency ablation as first-line therapy of early hepatocellular carcinoma: analysis of prognostic factors. J Hepatol 2013;58:89-97.

11. Smith I, Kahaleh M. Biliary Tumor Ablation with Photodynamic Therapy and Radiofrequency Ablation. Gastrointest Endosc Clin N Am 2015;25:793-804.

12. Yang J, Shen H, Jin H, et al. Treatment of unresectable extrahepatic cholangiocarcinoma using hematoporphyrin photodynamic therapy: A prospective study. Photodiagnosis Photodyn Ther 2016;16:110-8.

13. Wentrup R, Winkelmann N, Mitroshkin A, et al. Photodynamic Therapy Plus Chemotherapy Compared with Photodynamic Therapy Alone in Hilar Nonresectable
Cholangiocarcinoma. Gut Liver 2016;10:470-5.

14. Kahaleh M, Mishra R, Shami VM, et al. Unresectable Cholangiocarcinoma: Comparison of Survival in Biliary Stenting Alone Versus Stenting With Photodynamic Therapy. Clin Gastroenterol Hepatol 2008;6:290-7.

15. Hong MJ, Cheon YK, Lee EJ, et al. Long-term outcome of photodynamic therapy with systemic chemotherapy compared to photodynamic therapy alone in patients with advanced hilar cholangiocarcinoma. Gut Liver 2014;8:318-23.

16. Cheon YK, Lee TY, Lee SM, et al. Longterm outcome of photodynamic therapy compared with biliary stenting alone in patients with advanced hilar cholangiocarcinoma. HPB (Oxford) 2012;14:185-93.

17. Qureshi K, Jesudoss R, Al-Osaimi AM. The treatment of cholangiocarcinoma: a hepatologist's perspective. Curr Gastroenterol Rep 2014;16:412.

18. Razumilava N, Gores GJ. Classification, diagnosis, and management of cholangiocarcinoma. Clin Gastroenterol Hepatol 2013;11:13-21.e1; quiz e3-4.

19. Bismuth H, Corlette MB. Intrahepatic cholangioenteric anastomosis in carcinoma of the hilus of the liver. Surg Gynecol Obstet 1975;140:170-8.

20. Deoliveira ML, Schulick RD, Nimura Y, et al. New staging system and a registry for perihilar cholangiocarcinoma. Hepatology 2011;53:1363-71.

21. Uppal DS, Wang AY. Advances in endoscopic retrograde cholangiopancreatography for the treatment of cholangiocarcinoma. World J Gastrointest Endosc 2015;7:675-87.

22. Rustagi T, Jamidar P. Intraductal Radiofrequency Ablation for Management of Malignant Biliary Obstruction. Dig Dis Sci 2014;59:2635-41.

23. Dolak W, Schreiber F, Schwaighofer H, et al. Endoscopic radiofrequency ablation for malignant biliary obstruction: a nationwide retrospective study of 84 consecutive applications. Surg Endosc 2014;28:854-60.

24. Tal AO, Vermehren J, Friedrich-Rust M, et al. Intraductal endoscopic radiofrequency ablation for the treatment of hilar non-resectable malignant bile duct obstruction. World J Gastrointest Endosc 2014;6:13-9.

25. Wu TT, Li WM, Li HC, et al. Percutaneous Intraductal Radiofrequency Ablation for Extrahepatic Distal Cholangiocarcinoma: A Method for Prolonging Stent Patency and Achieving Better Functional Status and Quality of Life. Cardiovasc Intervent Radiol 2017;40:260-9.

26. Wang F, Li Q, Zhang X, et al. Endoscopic radiofrequency 
ablation for malignant biliary strictures. Exp Ther Med 2016;11:2484-8.

27. Wang Y, Cui W, Fan W, et al. Percutaneous intraductal radiofrequency ablation in the management of unresectable Bismuth types III and IV hilar cholangiocarcinoma. Oncotarget 2016;7:53911-20.

28. Laquière A, Boustiere C, LeBlanc S, et al. Safety and feasibility of endoscopic biliary radiofrequency ablation treatment of extrahepatic cholangiocarcinoma. Surg Endosc 2016; 30:1242-8.

29. Li TF, Huang GH, Li Z, et al. Percutaneous Transhepatic Cholangiography and Intraductal Radiofrequency Ablation Combined with Biliary Stent Placement for Malignant Biliary Obstruction. J Vasc Interv Radiol 2015;26:715-21.

30. Sharaiha RZ, Sethi A, Weaver KR, et al. Impact of Radiofrequency Ablation on Malignant Biliary Strictures: Results of a Collaborative Registry. Dig Dis Sci 2015;60:2164-9.

31. Wu TT, Li HC, Li WM, et al. Percutaneous Intraluminal Radiofrequency Ablation for Malignant Extrahepatic Biliary Obstruction: A Safe and Feasible Method. Dig Dis Sci 2015;60:2158-63.

32. Strand DS, Cosgrove ND, Patrie JT, et al. ERCP-directed radiofrequency ablation and photodynamic therapy are associated with comparable survival in the treatment of unresectable cholangiocarcinoma. Gastrointest Endosc 2014;80:794-804.

33. Sharaiha RZ, Natov N, Glockenberg KS, et al. Comparison of Metal Stenting with Radiofrequency Ablation Versus Stenting Alone for Treating Malignant Biliary Strictures: Is There an Added Benefit? Dig Dis Sci 2014;59:3099-102.

34. Mizandari M, Pai M, Xi F. Percutaneous Intraductal Radiofrequency Ablation is a Safe Treatment for Malignant Biliary Obstruction: Feasibility and Early Results. Cardiovasc Intervent Radiol 2013;36:814-9.

35. Alis H, Sengoz C, Gonenc M, et al. Endobiliary radiofrequency ablation for malignant biliary obstruction. Hepatobiliary Pancreat Dis Int 2013;12:423-7.

36. Figueroa-Barojas P, Bakhru MR, Habib NA, et al. Safety and efficacy of radiofrequency ablation in the management of unresectable bile duct and pancreatic cancer: a novel palliation technique. J Oncol 2013;2013:910897.

37. Steel AW, Postgate AJ, Khorshandi S, et al. Endoscopically applied radiofrequency ablation appears to be safe in the treatment of malignant biliary obstruction. Gastrointest Endosc 2011;73;149-53.

38. Patel J, Rizk N, Kahaleh M. Role of photodynamic therapy and intraductal radiofrequency ablation in cholangiocarcinoma. Best Pract Res Clin Gastroenterol 2015;29:309-18.

39. McCaughan JS Jr, Mertens BF, Cho C, et al. Photodynamic therapy to treat tumors of the extrahepatic biliary ducts. A case report. Arch Surg 1991;126:111-3.

40. Park DH, Lee SS, Park SE, et al. Randomised phase II trial of photodynamic therapy plus oral fluoropyrimidine, S-1, versus photodynamic therapy alone for unresectable hilar cholangiocarcinoma. Eur J Cancer 2014;50:1259-68.

41. Pereira SP, Aithal GP, Ragunath K, et al. Safety and long term efficacy of porfimer sodium photodynamic therapy in locally advanced biliary tract carcinoma. Photodiagnosis Photodyn Ther 2012;9:287-92.

42. Weigt J, Schneider M, Kandulski A, et al. Therapeutic Yield of Photodynamic Therapy for Hilar Cholangiocarcinoma. Gastroenterology 2011;140:S-595-S-596.

43. Quyn AJ, Ziyaie D, Polignano FM, et al. Photodynamic therapy is associated with an improvement in survival in patients with irresectable hilar cholangiocarcinoma. HPB (Oxford) 2009;11:570-7.

44. Fuks D, Bartoli E, Delcenserie R, et al. Biliary drainage, photodynamic therapy and chemotherapy for unresectable cholangiocarcinoma with jaundice. J Gastroenterol Hepatol 2009;24:1745-52.

45. Witzigmann H, Berr F, Ringel U, et al. Surgical and Palliative Management and Outcome in 184 Patients With Hilar Cholangiocarcinoma: Palliative Photodynamic Therapy Plus Stenting Is Comparable to R1/R2 Resection. Ann Surg 2006;244:230-9.

46. Zoepf T, Jakobs R, Arnold JC, et al. Palliation of Nonresectable Bile Duct Cancer: Improved Survival After Photodynamic Therapy. Am J Gastroenterol 2005;100:2426-30.

47. Ortner ME, Caca K, Berr F, et al. Successful photodynamic therapy for nonresectable cholangiocarcinoma: a randomized prospective study. Gastroenterology 2003;125:1355-63.

48. Matull WR, Dhar DK, Ayaru L, et al. R0 but not R1/R2 resection is associated with better survival than palliative photodynamic therapy in biliary tract cancer. Liver Int 2011;31:99-107.

49. Schmidt A, Bloechinger M, Weber A, et al. Short-term effects and adverse events of endoscopically applied radiofrequency ablation appear to be comparable with photodynamic therapy in hilar cholangiocarcinoma. United European Gastroenterol J 2016;4:570-9.

50. Prat F, Lafon C, Melo de Lima D, et al. Endoscopic 
treatment of cholangiocarcinoma and carcinoma of the duodenal papilla by intraductal high-intensity US: Results of a pilot study. Gastrointest Endosc 2002;56:909-15.

51. Ferlay J, Shin HR, Bray F, et al. Estimates of worldwide burden of cancer in 2008: GLOBOCAN 2008. Int J Cancer 2010;127:2893-917.

52. Alazawi $W$, Cunningham $M$, Dearden J, et al. Systematic review: outcome of compensated cirrhosis due to chronic hepatitis $\mathrm{C}$ infection. Aliment Pharmacol Ther 2010;32:344-55.

53. Bosetti C, Levi F, Boffetta P, et al. Trends in mortality from hepatocellular carcinoma in Europe, 1980-2004. Hepatology 2008;48:137-45.

54. Bruix J, Gores GJ, Mazzaferro V. Hepatocellular carcinoma: clinical frontiers and perspectives. Gut 2014;63:844-55.

55. Murray KF, Carithers RL Jr. AASLD practice guidelines: evaluation of the patient for liver transplantation. Hepatology 2005;41:1407-32.

56. Mazzaferro V, Regalia E, Doci R, et al. Liver transplantation for the treatment of small hepatocellular carcinomas in patients with cirrhosis. N Engl J Med 1996;334:693-9.

57. Toso C, Dupuis-Lozeron E, Majno P, et al. A model for dropout assessment of candidates with or without hepatocellular carcinoma on a common liver transplant waiting list. Hepatology 2012;56:149-56.

58. Avolio AW, Cillo U, Salizzoni M, et al. Balancing donor and recipient risk factors in liver transplantation: the value of D-MELD with particular reference to $\mathrm{HCV}$ recipients. Am J Transplant 2011;11:2724-36.

59. Bruix J, Sherman M. Management of hepatocellular carcinoma: an update. Hepatology 2011;53:1020-2.

60. Poon D, Anderson BO, Chen LT, et al. Management of hepatocellular carcinoma in Asia: consensus statement from the Asian Oncology Summit 2009. Lancet Oncol 2009;10:1111-8.

61. Freeman RB, Edwards EB, Harper AM. Waiting list removal rates among patients with chronic and malignant liver diseases. Am J Transplant 2006;6:1416-21

62. Llovet JM, Mas X, Aponte JJ, et al. Cost effectiveness of adjuvant therapy for hepatocellular carcinoma during the waiting list for liver transplantation. Gut 2002;50:123-8.

63. Fisher RA, Maluf D, Cotterell AH, et al. Non-resective ablation therapy for hepatocellular carcinoma: effectiveness measured by intention-to-treat and dropout from liver transplant waiting list. Clin Transplant 2004;18:502-12.

64. Sugiura N. Ultrasound image-guided percutaneous intratumor ethanol injection for small hepatocellular carcinoma. Acta Hepatologica Japonica 1983;24:920.

65. Livraghi T, Festi D, Monti F, et al. US-guided percutaneous alcohol injection of small hepatic and abdominal tumors. Radiology 1986;161:309-12.

66. Seki T, Wakabayashi M, Nakagawa T, et al. Ultrasonically guided percutaneous microwave coagulation therapy for small hepatocellular carcinoma. Cancer 1994;74:817-25.

67. Rossi S, Di Stasi M, Buscarini E, et al. Percutaneous radiofrequency interstitial thermal ablation in the treatment of small hepatocellular carcinoma. Cancer J Sci Am 1995;1:73-81.

68. Livraghi T, Goldberg SN, Lazzaroni S, et al. Small hepatocellular carcinoma: treatment with radiofrequency ablation versus ethanol injection. Radiology 1999;210:655-61.

69. Shiina S, Teratani T, Obi S, et al. A randomized controlled trial of radiofrequency ablation with ethanol injection for small hepatocellular carcinoma. Gastroenterology 2005;129:122-30.

70. Györi GP, Felsenreich DM, Silberhumer GR, et al. Multimodality locoregional treatment strategies for bridging HCC patients before liver transplantation. Eur Surg 2017;49:236-43.

71. Hao Y, Numata K, Ishii T, et al. Rate of local tumor progression following radiofrequency ablation of pathologically early hepatocellular carcinoma. World J Gastroenterol 2017;23:3111-21.

72. Liao M, Zhong X, Zhang J, et al. Radiofrequency ablation using a $10-\mathrm{mm}$ target margin for small hepatocellular carcinoma in patients with liver cirrhosis: A prospective randomized trial. J Surg Oncol 2017;115:971-9.

73. Rajyaguru DJ, Borgert AJ, Smith AL, et al. Radiofrequency Ablation Versus Stereotactic Body Radiotherapy for Localized Hepatocellular Carcinoma in Nonsurgically Managed Patients: Analysis of the National Cancer Database. J Clin Oncol 2018;36:600-8.

74. Parikh ND, Marshall VD, Green M, et al. Effectiveness and cost of radiofrequency ablation and stereotactic body radiotherapy for treatment of early-stage hepatocellular carcinoma: An analysis of SEER-medicare. J Med Imaging Radiat Oncol 2018;62:673-81.

75. Kitao A, Zen Y, Matsui O, et al. Hepatocarcinogenesis: multistep changes of drainage vessels at CT during arterial portography and hepatic arteriography--radiologicpathologic correlation. Radiology 2009;252:605-14.

76. Santambrogio R, Barabino M, Bruno S, et al. Surgical Resection vs. Ablative Therapies Through a Laparoscopic 
Approach for Hepatocellular Carcinoma: a Comparative Study. J Gastrointest Surg 2018;22:650-60.

77. Kalra N, Kang M, Duseja AK, et al. Comparison of radiofrequency ablation alone \& in combination with percutaneous ethanol injection for management of hepatocellular carcinoma. Indian J Med Res 2017;146:S30-7.

78. Zhang L, Wang N, Shen Q, et al. Therapeutic Efficacy of Percutaneous Radiofrequency Ablation versus Microwave Ablation for Hepatocellular Carcinoma. PLoS One 2013;8:e76119.

79. Abdelaziz AO, Abdelmaksoud AH, Nabeel MM, et al. Transarterial Chemoembolization Combined with Either Radiofrequency or Microwave Ablation in Management of Hepatocellular Carcinoma. Asian Pac J Cancer Prev 2017;18:189-94.

80. Bruix J, Sherman M, Practice Guidelines Committee, American Association for the Study of Liver Diseases Management of hepatocellular carcinoma. Hepatology 2005;42:1208-36.

81. Huang J, Yan L, Cheng Z, et al. A randomized trial comparing radiofrequency ablation and surgical resection for HCC conforming to the Milan criteria. Ann Surg 2010;252:903-12.

82. Pulvirenti A, Garbagnati F, Regalia E, et al. Experience with radiofrequency ablation of small hepatocellular carcinomas before liver transplantation. Transplant Proc 2001;33:1516-7

83. Fontana RJ, Hamidullah H, Nghiem H, et al. Percutaneous radiofrequency thermal ablation of hepatocellular carcinoma: a safe and effective bridge to liver transplantation. Liver Transpl 2002;8:1165-74.

84. Mazzaferro V, Battiston C, Perrone S, et al. Radiofrequency ablation of small hepatocellular carcinoma in cirrhotic patients awaiting liver transplantation: a prospective study. Ann Surg 2004;240:900-9.

85. Pompili M, Mirante VG, Rondinara G, et al. Percutaneous ablation procedures in cirrhotic patients with hepatocellular carcinoma submitted to liver transplantation: Assessment of efficacy at explant analysis and of safety for tumor recurrence. Liver Transpl 2005;11:1117-26.

86. Lu DS, Yu NC, Raman SS, et al. Percutaneous radiofrequency ablation of hepatocellular carcinoma as a bridge to liver transplantation. Hepatology 2005;41:11307.

87. Brillet PY, Paradis V, Brancatelli G, et al. Percutaneous radiofrequency ablation for hepatocellular carcinoma before liver transplantation: a prospective study with histopathologic comparison. AJR Am J Roentgenol 2006;186:S296-305.

88. DuBay DA, Sandroussi C, Kachura JR, et al. Radiofrequency ablation of hepatocellular carcinoma as a bridge to liver transplantation. HPB (Oxford) 2011;13:24-32.

89. Cho YK, Kim JK, Kim WT, et al. Hepatic resection versus radiofrequency ablation for very early stage hepatocellular carcinoma: a Markov model analysis. Hepatology 2010;51:1284-90.

90. Komorizono Y, Oketani M, Sako K, et al. Risk factors for local recurrence of small hepatocellular carcinoma tumors after a single session, single application of percutaneous radiofrequency ablation. Cancer 2003;97:1253-62.

91. Lencioni R. Loco-regional treatment of hepatocellular carcinoma. Hepatology 2010;52:762-73.

92. Livraghi T, Solbiati L, Meloni MF, et al. Treatment of focal liver tumors with percutaneous radio-frequency ablation: complications encountered in a multicenter study. Radiology 2003;226:441-51

93. International Consensus Group for Hepatocellular Neoplasia The International Consensus Group for Hepatocellular Neoplasia. Pathologic diagnosis of early hepatocellular carcinoma: a report of the international consensus group for hepatocellular neoplasia. Hepatology 2009;49:658-64.

94. Kudo M. Multistep human hepatocarcinogenesis: correlation of imaging with pathology. J Gastroenterol 2009;44 Suppl 19:112-8.

95. Sano K, Ichikawa T, Motosugi U, et al. Imaging study of early hepatocellular carcinoma: usefulness of gadoxetic acid-enhanced MR imaging. Radiology 2011;261:834-44.

96. Praktiknjo M, Krabbe V, Pohlmann A, et al. Evolution of nodule stiffness might predict response to local ablative therapy: A series of patients with hepatocellular carcinoma. PLoS One 2018;13:e0192897.

97. Chen MS, Li JQ, Zheng Y, et al. A prospective randomized trial comparing percutaneous local ablative therapy and partial hepatectomy for small hepatocellular carcinoma. Ann Surg 2006;243:321-8.

98. Liu Z, Zhou Y, Zhang P, et al. Meta-analysis of the therapeutic effect of hepatectomy versus radiofrequency ablation for the treatment of hepatocellular carcinoma. Surg Laparosc Endosc Percutan Tech 2010;20:130-40.

99. Elias D, Debaere T, Muttillo I, et al. Intraoperative use of radiofrequency treatment allows an increase in the rate of curative liver resection. J Surg Oncol 1998;67:190-1. 
100.Elias D, Goharin A, El Otmany A, et al. Usefulness of intraoperative radiofrequency thermoablation of liver tumours associated or not with hepatectomy. Eur J Surg Oncol 2000;26:763-9.

101. Choi D, Lim HK, Joh JW, et al. Combined hepatectomy and radiofrequency ablation for multifocal hepatocellular carcinomas: long-term follow-up results and prognostic factors. Ann Surg Oncol 2007;14:3510-8.

102. Shuto T, Kinoshita H, Hirohashi K, et al. Indications for, and effectiveness of, a second hepatic resection for recurrent hepatocellular carcinoma. Hepatogastroenterology 1996;43:932-7.

103. Sugimachi K, Maehara S, Tanaka S, et al. Repeat hepatectomy is the most useful treatment for recurrent hepatocellular carcinoma. J Hepatobiliary Pancreat Surg 2001;8:410-6.

104.Arii S, Teramoto K, Kawamura T, et al. Characteristics of recurrent hepatocellular carcinoma in Japan and our surgical experience. J Hepatobiliary Pancreat Surg 2001;8:397-403.

105. Nagasue N, Kohno H, Hayashi T, et al. Repeat hepatectomy for recurrent hepatocellular carcinoma. Br J Surg 1996;83:127-31.

106.Poon RT, Fan ST, Lo CM, et al. Intrahepatic recurrence after curative resection of hepatocellular carcinoma: longterm results of treatment and prognostic factors. Ann Surg 1999;229:216-22.

107. Nicoli N, Casaril A, Marchiori L, et al. Treatment of recurrent hepatocellular carcinoma by radiofrequency thermal ablation. J Hepatobiliary Pancreat Surg 2001;8:417-21.

108. Choi D, Lim HK, Kim MJ, et al. Recurrent hepatocellular carcinoma: percutaneous radiofrequency ablation after hepatectomy. Radiology 2004;230:135-41.

109.Lu MD, Yin XY, Xie XY, et al. Percutaneous thermal ablation for recurrent hepatocellular carcinoma after hepatectomy. Br J Surg 2005;92:1393-8.

110. Schindera ST, Nelson RC, DeLong DM, et al. Intrahepatic tumor recurrence after partial hepatectomy: value of percutaneous radiofrequency ablation. J Vasc Interv Radiol 2006; 17:1631-7.

111. Yang W, Chen MH, Yin SS, et al. Radiofrequency ablation of recurrent hepatocellular carcinoma after hepatectomy: therapeutic efficacy on early- and late-phase recurrence. AJR Am J Roentgenol 2006;186:S275-83.

112. Choi D, Lim HK, Rhim H, et al. Percutaneous radiofrequency ablation for recurrent hepatocellular carcinoma after hepatectomy: long-term results and prognostic factors. Ann Surg Oncol 2007;14:2319-29.

113. Liang HH, Chen MS, Peng ZW, et al. Percutaneous radiofrequency ablation versus repeat hepatectomy for recurrent hepatocellular carcinoma: a retrospective study. Ann Surg Oncol 2008;15:3484-93.

114. Chan AC, Poon RT, Cheung TT, et al. Survival analysis of re-resection versus radiofrequency ablation for intrahepatic recurrence after hepatectomy for hepatocellular carcinoma. World J Surg 2012;36:151-6.

115.Eisele RM, Chopra SS, Lock JF, et al. Treatment of recurrent hepatocellular carcinoma confined to the liver with repeated resection and radiofrequency ablation: a single center experience. Technol Health Care 2013;21:9-18.

116. Weber JC, Navarra G, Jiao LR, et al. New technique for liver resection using heat coagulative necrosis. Ann Surg 2002;236:560-3.

117.Pai M, Spalding D, Jiao L, et al. Use of bipolar radiofrequency in parenchymal transection of the liver, pancreas and kidney. Dig Surg 2012;29:43-7.

118.Pai M, Frampton AE, Mikhail S, et al. Radiofrequency assisted liver resection: analysis of 604 consecutive cases. Eur J Surg Oncol 2012;38:274-80.

119. Minami Y, Kudo M. Therapeutic response assessment of transcatheter arterial chemoembolization for hepatocellular carcinoma: ultrasonography, CT and MR imaging. Oncology 2013;84 Suppl 1:58-63.

120. Forner A, Llovet JM, Bruix J. Hepatocellular carcinoma. Lancet. 2012;379:1245-55.

121. Rossi S, Garbagnati F, Lencioni R, et al. Percutaneous radio-frequency thermal ablation of nonresectable hepatocellular carcinoma after occlusion of tumor blood supply. Radiology 2000;217:119-26.

122. Yamakado K, Nakatsuka A, Ohmori S, et al. Radiofrequency ablation combined with chemoembolization in hepatocellular carcinoma: treatment response based on tumor size and morphology. J Vasc Interv Radiol 2002;13:1225-32.

123. Bruix J, Sherman M. Management of hepatocellular carcinoma. Hepatology 2005;42:1208-36.

124.Lai EC, Lau WY. Hepatocellular carcinoma presenting with obstructive jaundice. ANZ J Surg 2006;76:631-6.

125. Qin LX, Tang ZY. Hepatocellular carcinoma with obstructive jaundice: diagnosis, treatment and prognosis. World J Gastroenterol 2003;9:385-91.

126. Lau W, Leung K, Leung TW, et al. A logical approach to hepatocellular carcinoma presenting with jaundice. Ann Surg 1997;225:281-5. 
127. Cho HC, Lee JK, Lee KH, et al. Are endoscopic or percutaneous biliary drainage effective for obstructive jaundice caused by hepatocellular carcinoma? Eur J Gastroenterol Hepatol 2011;23:224-31.

128. Chen MF, Jan YY, Jeng LB, et al. Obstructive jaundice secondary to ruptured hepatocellular carcinoma into the common bile duct. Surgical experiences of 20 cases. Cancer 1994;73:1335-40.

129. Hu J, Pi Z, Yu YM, et al. Obstructive jaundice caused by tumor emboli from hepatocellular carcinoma. Am Surg 1999;65:406-10.

130.Ikenaga N, Chijiiwa, K, Otani K, et al. Clinicopathologic characteristics of hepatocellular carcinoma with bile duct invasion. J Gastrointest Surg 2009;13:492-7.

131. Tang PM, Bui-Xuan NH, Wong CK, et al. Pheophorbide a-Mediated Photodynamic Therapy Triggers HLA Class I-Restricted Antigen Presentation in Human Hepatocellular Carcinoma. Transl Oncol 2010;3:114-22.

132. Daniell MD, Hill JS. A history of photodynamic therapy. Aust N Z J Surg 1991;61:340-8.

133. Kabingu E, Vaughan L, Owczarczak B, et al. CD8+ T cell-mediated control of distant tumours following local photodynamic therapy is independent of CD4+ T cells and dependent on natural killer cells. Br J Cancer 2007;96:1839-48.

134. Kousis PC, Henderson BW, Maier PG, et al. Photodynamic therapy enhancement of antitumor immunity is regulated by neutrophils. Cancer Res 2007;67:10501-10.

135. Castano AP, Mroz P, Hamblin MR. Photodynamic therapy and antitumour immunity. Nat Rev Cancer 2006;6:535-45.

136. Korbelik $M$. Induction of tumor immunity by photodynamic therapy. J Clin Laser Med Surg 1996;14:329-34.

137.van Duijnhoven FH, Aalbers RI, Rovers JP, et al. The immunological consequences of photodynamic treatment of cancer, a literature review. Immunobiology 2003;207:105-13.

138. Canti G, De Simone A, Korbelik M. Photodynamic therapy and the immune system in experimental oncology. Photochem Photobiol Sci 2002;1:79-80.

139. Robertson CA, Evans DH, Abrahamse H. Photodynamic therapy (PDT): a short review on cellular mechanisms and cancer research applications for PDT. J Photochem Photobiol B 2009;96:1-8.

140.Sharman WM, Allen CM, Van Lier JE. Role of activated oxygen species in photodynamic therapy. Methods
Enzymol 2000;319:376-400.

141. Triesscheijn M, Baas P, Schellens JH, et al. Photodynamic therapy in oncology. Oncologist 2006;11:1034-44.

142. Bahng S, Yoo BC, Paik SW, et al. Photodynamic therapy for bile duct invasion of hepatocellular carcinoma. Photochem Photobiol Sci 2013;12:439-45.

143.Mirzaei H, Djavid GE, Hadizadeh M, et al. The efficacy of Radachlorin-mediated photodynamic therapy in human hepatocellular carcinoma cells. J Photochem Photobiol B 2015;142:86-91.

144. Chang JE, Yoon IS, Sun PL, et al. Anticancer efficacy of photodynamic therapy with hematoporphyrin-modified, doxorubicin-loaded nanoparticles in liver cancer. J Photochem Photobiol B 2014;140:49-56.

145. Shirata C, Kaneko J, Inagaki Y, et al. Near-infrared photothermal/photodynamic therapy with indocyanine green induces apoptosis of hepatocellular carcinoma cells through oxidative stress. Sci Rep 2017;7:13958.

146. Douillard S, Olivier D, Patrice T. In vitro and in vivo evaluation of Radachlorin sensitizer for photodynamic therapy. Photochem Photobiol Sci 2009;8:405-13.

147. O'Connor AE, Gallagher WM, Byrne AT. Porphyrin and nonporphyrin photosensitizers in oncology: preclinical and clinical advances in photodynamic therapy. Photochem Photobiol 2009;85:1053-74.

148. Berg K, Selbo PK, Weyergang A, et al. Porphyrin-related photosensitizers for cancer imaging and therapeutic applications. J Microsc 2005;218:133-47.

149.Lee SJ, Park K, Oh YK, et al. Tumor specificity and therapeutic efficacy of photosensitizer-encapsulated glycol chitosan-based nanoparticles in tumor-bearing mice. Biomaterials 2009;30:2929-39.

150. Chen B, Pogue BW, Hasan T. Liposomal delivery of photosensitising agents. Expert Opin Drug Deliv 2005;2:477-87.

151.Peng CL, Shieh MJ, Tsai MH, et al. Self-assembled star-shaped chlorin-core poly(epsiloncaprolactone)poly(ethylene glycol) diblock copolymer micelles for dual chemo-photodynamic therapies. Biomaterials 2008;29:3599-608.

152. Lee SJ, Koo H, Jeong H, et al. Comparative study of photosensitizer loaded and conjugated glycol chitosan nanoparticles for cancer therapy. J Control Release 2011;152:21-9.

153. Canti G, Nicolin A, Cubeddu R, et al. Antitumor efficacy of the combination of photodynamic therapy and chemotherapy in murine tumors, Cancer Lett 
1998;125:39-44.

154. Casas A, Fukuda H, Riley P, et al. Enhancement of aminolevulinic acid based photodynamic therapy by adriamycin. Cancer Lett 1997;121:105-13.

155. Cho YH, Straight RC, Smith JA Jr. Effects of photodynamic therapy in combination with intravesical drugs in a murine bladder tumor model. J Urol 1992;147:743-6.

156. Baas P, Van Geel IP, Oppelaar H, et al. Enhancement of photodynamic therapy by mitomycin $\mathrm{C}$ : a preclinical and clinical study. Br J Cancer 1996;73:945-51.

157.Ismail AF, Ali MM, Ismail LF. Photodynamic therapy mediated antiproliferative activity of some metal-doped $\mathrm{ZnO}$ nanoparticles in human liver adenocarcinoma HepG2 cells under UV irradiation. J Photochem Photobiol B 2014;138:99-108.

158. Ishizawa T, Masuda K, Urano $Y$, et al. Mechanistic background and clinical applications of indocyanine green fluorescence imaging of hepatocellular carcinoma. Ann Surg Oncol 2014;21:440-8.

159. Shiina S, Yasuda H, Muto H, et al. Percutaneous ethanol injection in the treatment of liver neoplasms. AJR Am J Roentgenol 1987;149:949-52.

160. Ebara M, Okabe S, Kita K, et al. Percutaneous ethanol injection for small hepatocellular carcinoma: Therapeutic efficacy based on 20-year observation. J Hepatol 2005;43:458-64.

161. Shiina S, Tagawa K, Niwa Y, et al. Percutaneous ethanol injection therapy for hepatocellular carcinoma: Results in 146 patients. AJR Am J Roentgenol 1993;160:1023-8.

162.Sung YM, Choi D, Lim HK, et al. Long-term results of percutaneous ethanol injection for the treatment of hepatocellular carcinoma in Korea. Korean J Radiol 2006;7:187-92.

163. Shiina S, Tateishi R, Imamura M, et al. Percutaneous ethanol injection for hepatocellular carcinoma: 20 year outcome and prognostic factors. Liver Int 2012;32:1434-42.

164. Cho YK, Kim JK, Kim MY, et al. Systematic review of randomized trials for hepatocellular carcinoma treated with percutaneous ablation therapies. Hepatology 2009;49:453-9.

165. Germani G, Pleguezuelo M, Gurusamy K, et al. Clinical outcomes of radiofrequency ablation, percutaneous alcohol and acetic acid injection for hepatocelullar carcinoma: a meta-analysis. J Hepatol 2010;52:380-8.

166. Hoffmann NE, Bischof JC. The cryobiology of cryosurgical injury. Urology 2002;60:40-9.

167. Orlacchio A, Bazzocchi G, Pastorelli D, et al. Percutaneous cryoablation of small hepatocellular carcinoma with US guidance and CT monitoring: Initial experience. Cardiovasc Intervent Radiol 2008;31:587-94.

168. Brace CL, Laeseke PF, Sampson LA, et al. Microwave ablation with a single small-gauge triaxial antenna: In vivo porcine liver model. Radiology 2007;242:435-40.

169. Dodd GD 3rd, Dodd NA, Lanctot AC, et al. Effect of variation of portal venous blood flow on radiofrequency and microwave ablations in a blood-perfused bovine liver model. Radiology 2013;267:129-36.

170.Fan W, Li X, Zhang L, et al. Comparison of microwave ablation and multipolar radiofrequency ablation in vivo using two internally cooled probes. AJR Am J Roentgenol 2012;198:W46-50.

171.Lubner MG, Brace CL, Hinshaw JL, et al. Microwave tumor ablation: mechanism of action, clinical results, and devices. J Vasc Interv Radiol 2010;21:S192-203.

172. Varela M, Real MI, Burrel M, et al. Chemoembolization of hepatocellular carcinoma with drug eluting beads: efficacy and doxorubicin pharmacokinetics. J Hepatol 2007;46:474-81.

173. Salem R, Mazzaferro V, Sangro B. Yttrium 90 radioembolization for the treatment of hepatocellular carcinoma: biological lessons, current challenges, and clinical perspectives. Hepatology 2013;58:2188-97.

174. Salem R, Lewandowski RJ, Mulcahy MF, et al. Radioembolization for hepatocellular carcinoma using Yttrium-90 microspheres: a comprehensive report of longterm outcomes. Gastroenterology 2010;138:52-64.

175. Sangro B, Carpanese L, Cianni R, et al. Survival after yttrium-90 resin microsphere radioembolization of hepatocellular carcinoma across Barcelona clinic liver cancer stages: a European evaluation. Hepatology 2011;54:868-78.

176. Koda M, Ueki M, Maeda Y, et al. The influence on liver parenchymal function and complications of radiofrequency ablation or the combination with transcatheter arterial embolization for hepatocellular carcinoma. Hepatol Res 2004;29:18-23.

177.Kuroda H, Kasai K, Kakisaka K, et al. Changes in liver function parameters after percutaneous radiofrequency ablation therapy in patients with hepatocellular carcinoma. Hepatol Res 2010;40:550-4.

178. Lee EW, Chen C, Prieto VE, et al. Advanced hepatic ablation technique for creating complete cell death: 
Irreversible electroporation. Radiology 2010;255:426-33. 179. Cannon R, Ellis S, Hayes D, et al. Safety and early efficacy of irreversible electroporation for hepatic tumors in proximity to vital structures. J Surg Oncol 2013;107:544-9.

doi: $10.21037 / \operatorname{tgh} .2019 .10 .17$

Cite this article as: Satiya J, Schwartz I, Tabibian JH, Kumar V, Girotra M. Ablative therapies for hepatic and biliary tumors: endohepatology coming of age. Transl Gastroenterol Hepatol 2020;5:15.
180. Kingham TP, Karkar AM, D'Angelica MI, et al. Ablation of perivascular hepatic malignant tumors with irreversible electroporation. J Am Coll Surg 2012;215:379-87. 